\title{
Correcting the Incorrect: An Exploratory Study into the Role of the Controller in Counteracting Financial Fake News ${ }^{1}$
}

\author{
W. Veldman \\ Rijksuniversiteit Groningen, \\ Faculty of Economics and Business, The Netherlands \\ D. M. Swagerman \\ Rijksuniversiteit Groningen, \\ Faculty of Economics and Business, The Netherlands
}

\begin{abstract}
This study aims to provide a foundation for an initial exploratory theory about the role of the controller in counteracting financial fake news. To accomplish this, the efforts against the dissemination of financial fake news were explored at the overall, societal, segmental, firm and function level. The Constructivist Grounded Theory Method is used to generate a conceptual model out of those five levels of analysis. As part of this approach, data from open interviews with ten respondents and key informants are used to gain insights into the efforts against the phenomenon of financial fake news. Thereafter, the results were analysed in a phenomenological oriented way to draw conclusions from it. This study concludes that the rational considerations one makes to discover to truth are embedded in the role of the controller as 'being the conscience of the firm'. Nevertheless, financial fake news is a complex phenomenon that is rather an assessment or judgement than a measurable fact, whereby its complexity stems from the phenomenon's multidimensional characteristics. Possible misconceptions regarding news can arise due to ignorance of reality. Therefore, intervention in the form of countermeasures is of importance from a social point of view. On the contrary, it can be questioned whether these interventions are necessary from an economic point of view, since general benefit of society at large is created when everyone is pursuing their own interests. The way in which financial fake news should be counteracted thus depends on the perspective in which the problem is approached.
\end{abstract}

Keywords: financial fake news; controller; constructivist grounded theory method; systems theory; qualitative research; exploratory research.

\section{INTRODUCTION}

The first paragraph of this section will introduce the subject, where after the second paragraph will introduce the social context in which this study takes place. From there, the main research question and operational research questions will be formulated in the third paragraph. The scientific contribution of this research will be explained in the fourth paragraph. Finally, the outline of this paper will be given in the last paragraph.

\section{Introduction}

Fake news is a frequently used term in the current days that arises in all kinds of ways and for different purposes. Political fake news can, for instance, be used as a means to sow discord in other countries (Klok, 2017; Hosenball \& Menn, 2017). Likewise, a fake news article stated that ImmunoCellular Therapeutics developed an innovative and thus competing product (Flood,

\footnotetext{
1 This article is based on the Master of Sciences thesis of Willeke Veldman, the content of this article is a further extension of their thesis.
} 
2017), which resulted in artificial inflation of stock prices. Once the truth has been uncovered, the stock rates dropped to the disadvantage of shareholders who bought in a high price (Kimmel, 2010). These two examples illustrate causes for confusion and concerns among many people about the dissemination of fake news. This is also evident from a current study of I\&O Research (2017) into the influence of fake news on the social debate. Their primary findings were that fake news potentially causes confusion among its readers and evokes an increase in the distrust of news sources. They conclude that at least 82 percent of the target audience believes fake news could lead to a threat to democracy. Moreover, according to the well-known philosopher and pragmatist James (1907), the importance of having no confusions about matters of fact is generally known in this world that can be "infinitely useful or infinitely harmful" (p. 143). It can thus be concluded that a closer look into the current state of fake news is needed.

\section{Social relevance}

Fake news has been an integral part of politics and journalism for ages (Lloyd, 2017). It already played a role in the time of Ancient Rome, but was also instigation for the crusades and witch hunts (Van der Horst, 2018). In addition, historical figures such as Bismarck ${ }^{2}$ and Goebbels ${ }^{3}$ tactically used fake news to achieve their goals by outlining an enemy who did not exist (Horlings, 2018).

Orwell already predicted a world in which fake news predominates in his novel '1984'4 His prophesy corresponds to today's reality in the collective struggle of society to uphold the truth (NU.nl, 2018). However, he could probably not have imagined the considerable role of the Internet within today's society and its strongly developed interrelation with fake news over the years. The Internet offers a perfect opportunity to disseminate news on a large scale, at relative low costs and in real time. In modern societies, most people have direct and easily access to news via, for instance, search engines and social media platforms (Allcot \& Gentzkow, 2017; Keersmaecker \& Roets, 2017; Kimmel, 2010). Other incentives to disseminate fake news are the simplicity of distributing fake articles, the simplicity of creating websites and the advertising revenues for websites that use fake news as 'clickbait's (Fm.nl, 2017).

When people with false motives disseminate fake news, it can become pernicious to society and, more specifically, to the financial community as it has the ability to disseminate rapidly and has the power to damage the firm's reputation (Kuchler, 2017). Fake news is therefore not only used for political purposes, but also for generating earnings at the expense of companies and consumers and hence for hurting these parties financially (Verhagen, 2017). These aspects have led to an increasing call to tackle the dissemination of financial fake news (Kreijveld, 2018a).

\section{Problem definition and research goal}

Considering the previously mentioned concerns of the Dutch people as the subject of this study and the increasing impact of this pernicious phenomenon, financial fake news is of growing importance to society. A study into the ways of counteracting the dissemination of financial

\footnotetext{
${ }^{2}$ Prime Minister of Prussia who played a central role in the realisation of the German Empire in 1871. He can be seen as a master in manipulating the media and public opinion (Koops, 2017).

3 Minister of propaganda in Nazi Germany (Historiek, 2015).

${ }^{4}$ Orwell's novel '1984' is set in an imaginary future in which the world is dominated by three totalitarian police states. The government of one of those states perpetuates its rule by systematically distorting the truth and continuously rewriting history to suit its own purposes (Woodcock, n.d.).

${ }^{5} \mathrm{~A}$ website link designed to lure internet users to visit a certain website.
} 
fake news will therefore be conducted at five levels of analysis (see Figure 1) while working towards the 'function level'. In this study, the controlling function is chosen to consider at the function level, since the controller plays an essential role in managing the firm's risks (De Loo, Verstegen \& Swagerman, 2011). The ultimate goal of this study is to develop a conceptual model that can explain the role of the controller in the current fight against financial fake news, so that new insights can be provided for better control in practice. The research question is, subsequently, as follows: How is the role of the controller embedded in counteracting the dissemination of financial fake news?

In answering the research question on the previous page, the efforts against the dissemination of financial fake news will first be explored at the overall level, followed by the societal level, segmental level and firm level. Consequently, the operational research questions are derived deductively from the main question and thus a top-down design was applied when drawing up the questions (see Figure 1).

Figure 1 : Top-down design

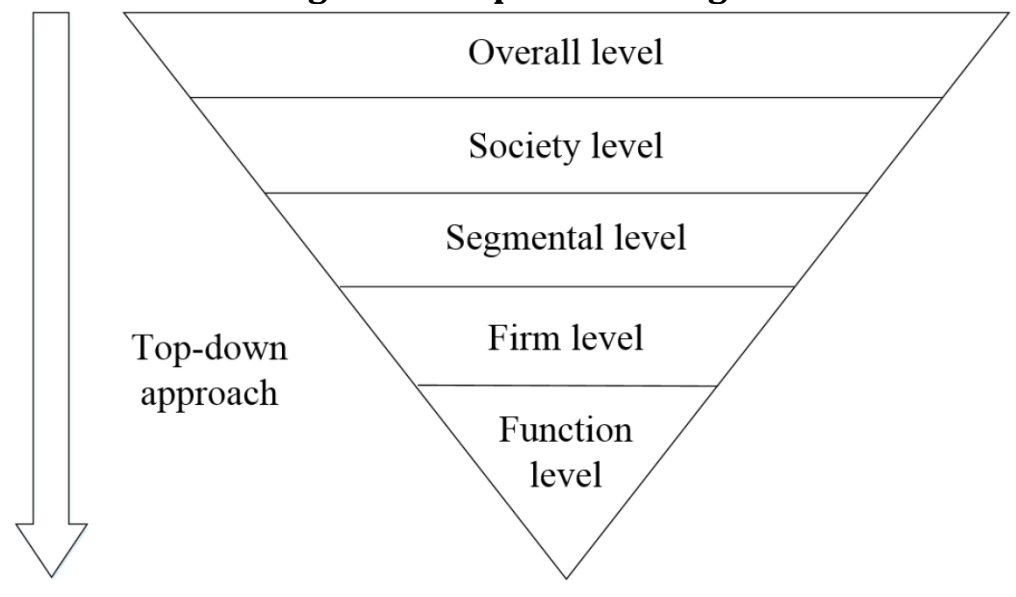

The phenomenon of interest will be explored on five levels in a top-down approach, which results in a set of sub-questions specified for each of these stages. The main question will thus be answered through answering the following sub-questions:

1. How can financial fake news be defined?

2. How are the dissemination and mitigation of financial fake news embedded at society level?

3. How is financial fake news positioned within the segment of large firms?

4. How are the dissemination and mitigation of financial fake news embedded at firm level?

5. What is the role of the controller within the firm?

For the second, third and fourth sub question, the underlying structures are identified to gain a solid understanding about the dissemination of financial fake news. These structures refer to the systems and its deeper patterns and systemic structures by which emerge of financial fake news is driven (Kim, 1999). Before these underlying structures can be determined, financial fake news must be defined first. Since fake news seems to have become a collection bin of various phenomena (Kreijveld, 2018b), a clear definition will be given to clarify on which phenomena this study exactly focuses. In order to explore the matter at the firm level, financial fake news will first be positioned within the segment of large firms. Thereafter, the underlying structures can help in analysing the responses within the Dutch society, the firms investigated and the role of the controller in this response. The fact that the aforementioned operational 
sub-questions lead to problems of scope is taken into account in the various sections of this paper.

\section{Academic contribution}

This study contributes to the economics and business administration literature in three distinctive ways. First, it will provide an in depth analysis of the term 'financial fake news' in the academic field of economics and business administration. Currently, limited research exists concerning fake news in these fields of scientific research. In politics, the exposure of fake news potentially influences voting behaviour (Allcot \& Gentzkow, 2017), which can be caused by a voter's unconscious desire to sustain optimistic beliefs (Levy, 2014). Fake news may also impose private and social costs on society by making it more challenging for people to infer the true meaning of it (Allcot \& Gentzkow, 2017). Besides politics and society, the economy has also felt the detrimental impact of fake news (Kimmel, 2010). Through exploring the current state of affairs in counteracting financial fake news, this study will act as an early exploration that can contribute at establishing a foundation for further specified research concerning fake news.

Second, this study will explore the process of disseminating financial fake news on five different levels. Given the several ways fake news can be disseminated, it appears that there is no simple explanation for why society tends believe it (Kimmel, 2004). Moreover, the power of negative rumours depends on the extent to which society believes it (Jia, Ruan \& Zhang, 2017) in which human values play a substantive role in the establishment of expectations or understandings about, and thereby trust towards, firms (Devos, Spini \& Schwartz, 2002). From a scientific perspective, it would therefore be desirable to provide new insights about the underlying reasons of the preventative and reactive measures taken.

Third, this study will focus on the role of the firm and, more specifically, on the role of the controller in counteracting financial fake news. The role of the media and government on fake news, and vice versa, is discussed in several previous studies (Peress, 2014; Glaeser \& Ujhelyi, 2010), but the role of the firm has, insofar as this is known, been neglected. At the firm level, organisational risks including the risks arising from fake news should be controlled. The controller compiles the risk portfolios that assist management in making risk-based decisions (De Loo et al., 2011). Since the controller plays such a fundamental role in the risk management of firms, more knowledge of its role in the efforts against financial fake news is desired.

In summary, the state of the art in research is that various studies are conducted about the role of fake news in politics (Allcot \& Gentzkow, 2017; Levy, 2014), yet there is little to no evidence about the role of financial fake news in business.

\section{Outline of the paper}

In the remainder of this paper, first the research methodology of this study will be explained in the second section. Thereafter the theoretical framework will be elaborated in the third section. The results will be presented in the fourth section. Finally, the conclusion will be presented and discussed in the fifth section. Additionally, several suggestions for future research and for practice will be given in fifth section.

\section{RESEARCH METHODS}

In this section, the methods for gathering and evaluating evidence to answer the operational research questions will be elaborated. The research methods will be based on the qualitative research approach, as will be described in the first paragraph. The choice for the grounded 
theory method will be explained in the second paragraph, followed by the chosen research units in the third paragraph. Finally, the ways of collecting and analysing data will successively be covered in the fourth and fifth paragraph.

\section{Type of research}

A qualitative approach is chosen because of the exploratory nature of this study. Qualitative research methods can, in line with the goal of this study, "be used to provide great insight into the framing of practice in context" (Radcliffe, 2010, p. 703) and are used to gather information about business processes, actions and structures. Next to that, qualitative research is suitable for gaining a solid understanding of key individuals' experiences concerning the phenomenon of financial fake news and how they interpret these experiences (Bluhm, Harman, Lee \& Mitchell, 2011). Their experiences and the meaning of those experiences contribute in developing the conceptual model by denoting new insights and points of attention. This way, the findings can be analysed in a reflective way (Moustakas, 1994).

To accomplish this, a limited field study was conducted among key players and experts within the five levels of exploration. A limited field study approach is chosen because of four main reasons. First, given the restricted timeframe and context of this study, field research is the most appropriate qualitative research method (Lillis \& Mundy, 2005). Moreover, it can obtain detailed data about the underlying processes of the dissemination of and fight against financial fake news. Also, it can, consistent with the exploratory nature of this study, uncover elements of key individuals' experiences that are unknown (Blackstone, 2012). Finally, in this approach, not only the characteristics of the dissemination of and fight against financial fake news can be described, but also connections and differences between those characteristics can be explored (Baarda, De Goede \& Teunissen, 2013). The latter was done by using an existing formal theory - the systems theory - as a tool to properly describe the place of the controller within the underlying structures of counteracting financial fake news (Baarda et al., 2013). This way, the roles of different controllers can be compared in light of similarities and differences on an indepth level, which contributes to answering to research question. Nevertheless, in view of the exploratory nature of the research, it must be highlighted that the exploration on five levels prevents that breath will not be sacrificed in exchange for depth (Blackstone, 2012).

\section{Grounded Theory Method}

The methodological approach taken in this study is the Constructivist Grounded Theory Method (GTM) ${ }^{6}$ with a phenomenological orientation (Charmaz, 2014; Moustakas, 1994). The Constructivist view on truth underlines the emphasis put on the construction - as opposed to the discovery - of a theory in data by GTM (Bryant, 2017). According to Creswell (2009), GTM can be seen as "a general, abstract theory of process, action, or interaction grounded in the views of participants in a study" (p. 13 \& 229), which means that theories need to be created in terms of the differences they make to individual's understanding, judgements and actions (Bryant, 2017). The phenomenological orientation implies that the researcher delves more deeply into the experiences of the interviewees to consider the phenomenon of interest "from the inside" (Charmaz \& McMullen, 2011, p. 293).

When choosing a suitable method for this study, the GTM will first comprehensively be compared with the qualitative content analysis, as these two methods are quite similar to each other. However, they also have a number of distinctive features (Cho \& Lee, 2014). The

${ }^{6}$ Charmaz her version of the GTM is rooted in pragmatism and relativist epistemology in research practice. 
decision made is based on the goals of both methods, the rationale of this study and the characteristics of both methods among which the different coding processes.

To begin with, the goal of GTM is to develop a theory that explains a phenomenon of interest that is both relevant and problematic for those being studied (Charmaz, 2014; Corbin \& Strauss, 2008; Glaser, 1978). A distinctive advantage of qualitative content analysis is that it supports both an inductive and deductive approach. This advantage is, however, not relevant for this study as the deductive approach 1) is the best suitable one in exploring the different levels of a phenomenon that are inadequately explained by existing literature, and, 2) is also supported by the GTM (Cho \& Lee, 2014). Thereby, although both theories follow coding processes, the focus of these processes differs. While GTM focuses on theory building, qualitative content analysis focuses on extracting categories from the data collected (Cho \& Lee, 2014). Consequently, it can be concluded that a focus on theory building is more suitable within the scope of this study as prior knowledge regarding the phenomenon of interest is limited.

In the following stage of choosing a suitable method, the original pragmatic GTM of Glaser (1978), Corbin and Straus (2008) is compared with two well-known elaborations of it: the constructivist GTM of Charmaz (2014) and the 'Situational Analysis' (SA) of Clarke (2005). The decisive difference between the SA and constructivist GTM resulting in the choice for the latter, is that 'a situation' is the most important unit of analysis in the SA. This differs from the constructivist GTM, which concentrates on the social processes through human action and thus best fits within the scope of this study (Clarke, Friese \& Washburn, 2016). In addition, using the SA would have no added value given that there are no case studies analysed in this study. The constructivist approach is more suitable than the original pragmatic one, because it positions the researcher as co-producer by analysing "the situation, the interaction, the person's affect and [their] percept of how the interview went" (Charmaz, 1995, p. 33). This focus contributes to the reflection and interpretation that are, given the nature of the research subject, important aspects of this study. It must be noted, however, that the founder of the Constructivist GTM prefers multifaceted and narrative results rather than a detailed conceptual model. In this study, it is decided to deviate from this preference by adding a conceptual model to the conclusion and discussion section, because it gives a clear overview of the important concepts. This way, the model enables the reader to see at a glance the interrelated findings and consequently increases the readability and comprehensibility of this report. In the final stage of choosing a suitable method, preference is given to the constructivist GTM along with a phenomenological orientation in a complementary manner for the following reasons: 1) both have complementary yet distinctive features (Charmaz, 2014; Charmaz \& McMullen, 2011), 2) given the restricted timeframe of this study and the fact that the constructivist GTM invokes specific methodological strategies for speeding up the analytical process, GTM is more suitable as the fundamental methodology (Charmaz \& McMullen, 2011), and, 3) Katsirikou and Lin (2017) state that adding a phenomenological aspect in the methodology enables the researcher to consider more deeply the "essence of the experience of the phenomenon for those experiencing it" (p. 470), which cannot be revealed by ordinary observation (Katsirikou \& Lin, 2017; Sanders, 1982). The GTM serves, thus, as a tool in gaining insights on a more profound level (Katsirikou \& Lin, 2017; Moustakas, 1994), while the phenomenological orientation highlights the underlying essence of the interviewees' responses. The related research process will be shown in figure below. 
Figure 2 : Visual representation of the Constructivist GTM (from Charmaz, 2014)

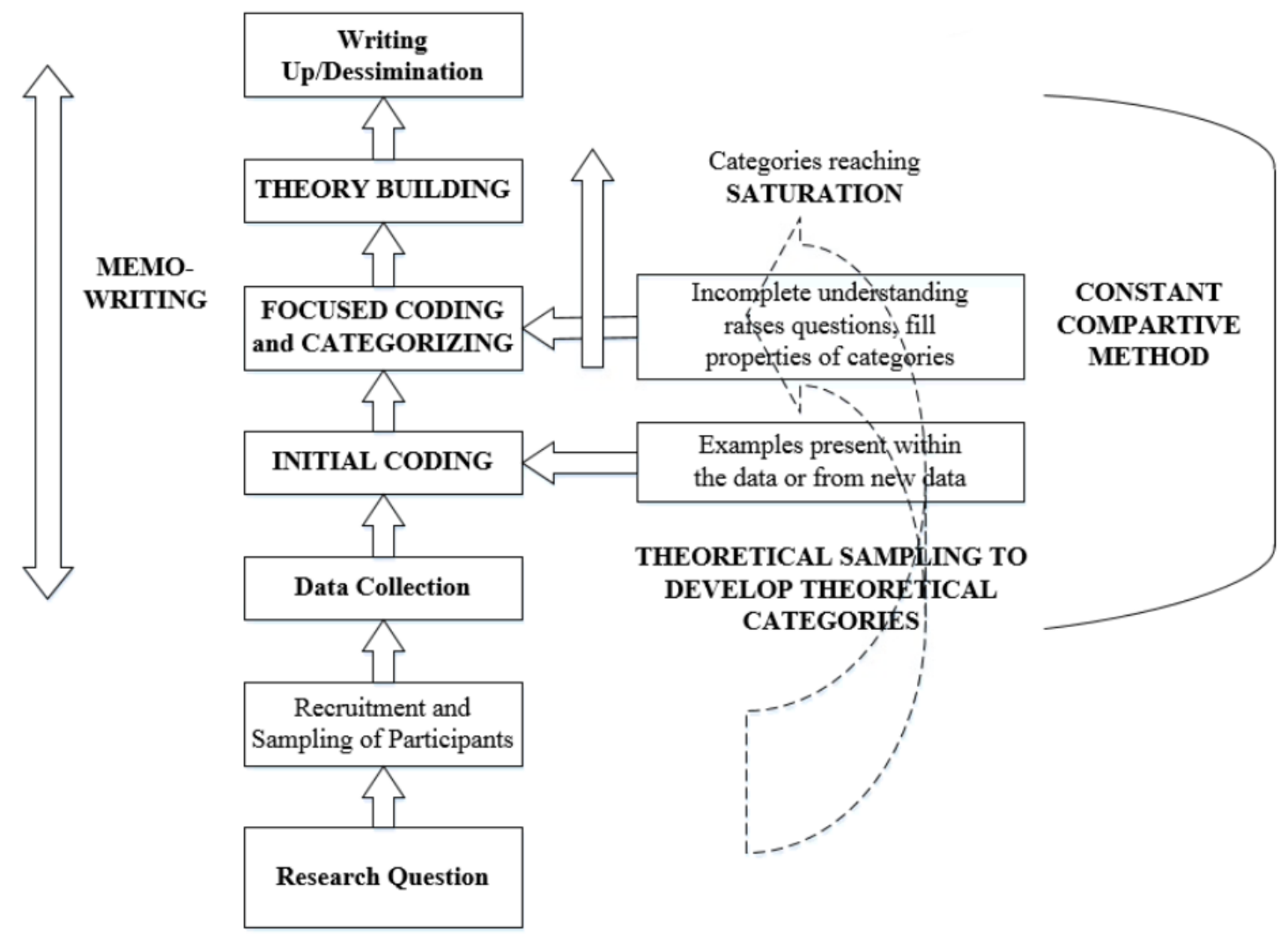

The Constructivist GTM is characterised by the possibility to deviate from this linear form as analytical connections can be made any time during the research process. As can be seen in the figure, a feature of the GTM is the absence of a theoretical framework section that serves to guide the data collection (Corbin \& Straus, 2008; Glaser, 1978). By contrast, in this study, a theoretical framework section was written before collecting the data with the aim to elaborate initial 'sensitizing concepts' arising from literature studied. Sensitizing concepts provide a theoretical base for its development, indicate the direction in which the researcher must look to answer the research question and can thus be seen as a starting point for a qualitative study (Bowen, 2006; Charmaz, 2014). The initial sensitizing concepts that can be derived from the problem definition and operational research questions are as follows:

- The underlying philosophy of individuals in processing financial fake news;

- The source of financial fake news;

- Underlying systemic structures of financial fake news;

- The role of the controller.

To understand the underlying philosophy of individuals in processing financial fake news, insight is required in philosophies underlying the questions such as 'What does one consider as truth?' and 'What is truth?' Furthermore, the assumption made in this study is that the source of financial fake news is an important factor in the dissemination of financial fake news considering that people make assumptions based on the knowledge they have about the reliability of the source (Horlings, 2018). Another assumption is that knowledge of the underlying systemic structures enhances the understanding about the dissemination of financial fake news (Kim, 1999). The final assumption is that the role of the controller in general could provide directions for identifying the role of the controller in counteracting financial fake news. As the GTM serves as a guide in the methods section, it will also be incorporated in the remaining paragraphs of this section. 


\section{Research units}

As mentioned in the introduction, financial fake news can have a harmful effect on firms with a certain level of financial dependency. Controllers contribute to the fight against financial fake news at the function level, as they have to identify and assess risks arising from financial fake news. Within this context, the research units are controllers of large firms. These firms meet the size criteria of the Dutch Civil Code $^{7}$ and are located in the Netherlands. This condition has been set because larger firms are widely known, but also have a large circle of stakeholders whose perception of the firm must remain positive to prevent a decline in profits (Gray \& Balmer, 1998; Homburg, Klarmann \& Schmitt, 2010). It is therefore assumed that firms with these characteristics, particularly when they are publicly listed, are proactively reducing the risk of being subjected to financial fake news to protect their businesses and to give confidence to their stakeholders (Devos et al., 2002; Gray \& Balmer, 1998).

Both respondents and several key informants were selected to interview. To reach the controller level, the phenomenon of financial fake news was first studied at higher levels of exploration. Therefore the respondents are linked with the efforts against financial fake news in a certain way, while key informants are experts who can provide information about the matter (Baarda et al., 2013). On society level, Dutch authorities that act against fake news were selected. On segmental and firm level, consultancy firms in the field of risk management were selected. In addition, employees from different large firms that are practicing or have practiced controlling related activities are selected. Finally, on function level, those same controllers were selected. The overall level includes all interviewees. Thus, different types of experts were initially selected to explore the various levels. During the interviews, however, it occurred that the experts also provided relevant information related to the other levels of exploration of the phenomenon of financial fake news.

\section{Data collection}

As part of the qualitative field study approach, primary data were collected through unstructured interviews and observations, while secondary data were collected through a literature study. Given the fact that the efforts against financial fake news were explored up to the function level, interviews have been the most suitable way to obtain the desired research data as they give the ability to do an in-depth analysis (Doyle, 2004). More specifically, an unstructured way of interviewing was used because of its flexibility to modify interview procedures and themes as needed to align with the background of the interviewees (Doyle, 2004). Besides that, deviation from the predetermined interview themes has been made possible as the interviewees could come up with relevant new insights or themes regarding financial fake news. Unstructured interviews also enable the interviewees to response in a richer and more flexible way, while the predetermined themes can be addressed during the interview in order to answer the research question (Smith, 2017). A literature study was performed to provide insights into the existing knowledge and theories concerning the research subject (Baarda et al, 2013). In line with the GTM, sensitizing concepts and a guiding theoretical framework are elaborated through literature study (Bowen, 2006). The results of the literature study are presented in the third section. With the acquired knowledge from the literature study, informed interview questions can be formulated (Qu \& Dumay, 2011).

On the following page, the table illustrates which methods are used to answer the sub questions previously mentioned.

\footnotetext{
7 The size criteria are included in Title 9 of Book 2 of the Dutch Civil Code.
} 


\begin{tabular}{|c|c|}
\hline Sub-questions & Research tool(s) / technique(s) \\
\hline How can financial fake news be defined? & $\begin{array}{l}\text { Literature study on the philosophies underpinning 'truth' and } \\
\text { on definitions used in existing literature. Additional insights } \\
\text { are gained through conducting interviews and making } \\
\text { observations. }\end{array}$ \\
\hline $\begin{array}{l}\text { How are the dissemination and } \\
\text { mitigation of financial fake news } \\
\text { embedded at society level? }\end{array}$ & $\begin{array}{l}\text { Literature study on suitable theories for conceptualising the } \\
\text { underlying structures to select a directive theoretical } \\
\text { framework on the basis of which financial fake news can be } \\
\text { embedded at society level. Subsequently, interviews with } \\
\text { Dutch authorities and other key informants are conducted to } \\
\text { obtain insights into the current situation of counteracting } \\
\text { financial fake news within the Dutch society. }\end{array}$ \\
\hline $\begin{array}{l}\text { How is financial fake news positioned } \\
\text { within the segment of large firms? }\end{array}$ & $\begin{array}{l}\text { Literature study on suitable theories for conceptualising the } \\
\text { underlying structures to select a directive theoretical } \\
\text { framework on the basis of which financial fake news can be } \\
\text { positioned within the segment of large firms. Subsequently, } \\
\text { interviews with key informants and respondents related to } \\
\text { the selected firms are conducted to obtain insights into the } \\
\text { influence of the firm size and firm type on the position of fake } \\
\text { news in the firm's policy. }\end{array}$ \\
\hline $\begin{array}{l}\text { How are the in the dissemination and } \\
\text { mitigation of financial fake news } \\
\text { embedded at the firm level? }\end{array}$ & $\begin{array}{l}\text { Literature study on suitable theories for conceptualising the } \\
\text { underlying structures to select a directive theoretical } \\
\text { framework on the basis of which the dissemination of } \\
\text { financial fake news can be constructed. Subsequently, } \\
\text { unstructured interviews with key informants and } \\
\text { respondents related to the selected firms are conducted to } \\
\text { explore the role of firms in counteracting financial fake news. }\end{array}$ \\
\hline $\begin{array}{l}\text { What is the role of the controller within } \\
\text { the firm? }\end{array}$ & $\begin{array}{l}\text { Literature study on the role of the controller to identify their } \\
\text { current role in general. Subsequently, unstructured } \\
\text { interviews with controllers of the selected firms are } \\
\text { conducted to obtain insights into their role in the fight against } \\
\text { financial fake news for that specific firm. }\end{array}$ \\
\hline
\end{tabular}

The first step in the iterative process of data collection and analysis was to collect secondary data about fake news matters. Main newspapers with a financial and business focus including 'Het Financieele Dagblad', 'Business Insider', and 'Financial Times' were consulted. By using a timeframe of fifteen years, the current situation of the rapid dissemination of information, which is enabled by the Internet (Kimmel, 2004), can be included in the research.

Unstructured interviews are then conducted in order to gain insights into the interviewees' experiences concerning financial fake news and their view on relevant issues including financial fake news in general, possible consequences of financial fake news, measures to counteract this phenomenon, the role of the controller and the role of other players (i.e. legislators and institutions)

In this matter; the questions followed initially the sequence of the above-mentioned main topics but were asked in a general and open manner to provide the opportunity for deviating from the main topics.

The interviewees are contacted through e-mail to participate on a voluntary basis. Depending on their relationship with the research subject, the interviewees were requested to explain their approach in counteracting on financial fake news and/or to explain their view on the matter. Also a number of specific questions were formulated based on interim findings of already conducted interviews. Then the interviewees' answers were coded and analysed compliant with the GTM. 
The interviewees were informed of the essential themes that would be discussed. Each interview was, with the prior consent of the interviewee, tape-recorded, transcribed, and subjected to constant comparative analysis and theoretical sampling (Charmaz, 1995; Glaser \& Strauss, 1967). Constant comparative analysis is a method for analysing data that will be explained in Section 2.5. In practical terms, applying the constant comparative analysis means that every interview, if possible, is transcribed and analysed before the next interview takes place. Relevant findings are documented and incorporated in the following interview. This alternation of data collection and data analysis was repeated, with data saturation being reached. Data saturation is reached when no new themes, categories, connections and underlying patterns arise and new data validates findings from prior data (Glaser \& Strauss, 1967). This may result in a deviation between the first interviews and the last interviews. The number of interviews conducted is based on this principle (Gasson, 2004). Theoretical sampling is an iterative process of selecting "incidents, slices of life, time periods, or people on the basis of their potential manifestation or representation of important theoretical constructs" (Patton, 2002, p. 238). In practical terms, this means that the individuals interviewed are selected based on their relevance to theory construction.

All of the interviews started with a short introduction concerning the objectives of this study. Ten interviews were conducted in person, from the period March until May 2018, and lasted between fifteen and 45 minutes. During the interviews, key words were noted to discover the main findings of the answers given by the interviewees in a more effective way.

\section{Data analysis and coding}

In attempting to identify as precisely as possible what conclusions can be drawn from the collected data, data analysis is being done with 'thinking in systems' on the one hand and is based on GTM on the other hand. 'Thinking in systems' originates from the Systems Theory and will be used to focus on deeper patterns and systemic structures that drive financial fake news. Following the procedures of the GTM as described by Charmaz (2016), data were coded in order to analyse the data (see appendix). Through a process of reduction and labelling, a conceptual model was developed in Section 5.1 (Baarda et al., 2013).

In the GTM, data collection and analysis run parallel. The data collected were first analysed for "theoretical constructs, themes, and patterns that are grounded in the theory" (Gall, Borg, \& Gall, 1996, p. 52). The cycle of data collection is characterised by data analysis and reflection; the next step in data collection is based on the outcomes of data analysis and reflection. By doing this, a conceptual model can systematically be developed (Corbin \& Strauss, 2008; Charmaz, 2014). The cycle is conceptualised in figure 3 below and can be characterised as an iterative process of qualitative analysis with an inductive approach. 
Figure 3 : GTM constant comparative analysis (From Kohn, L., \& Christiaens, W. (2012).

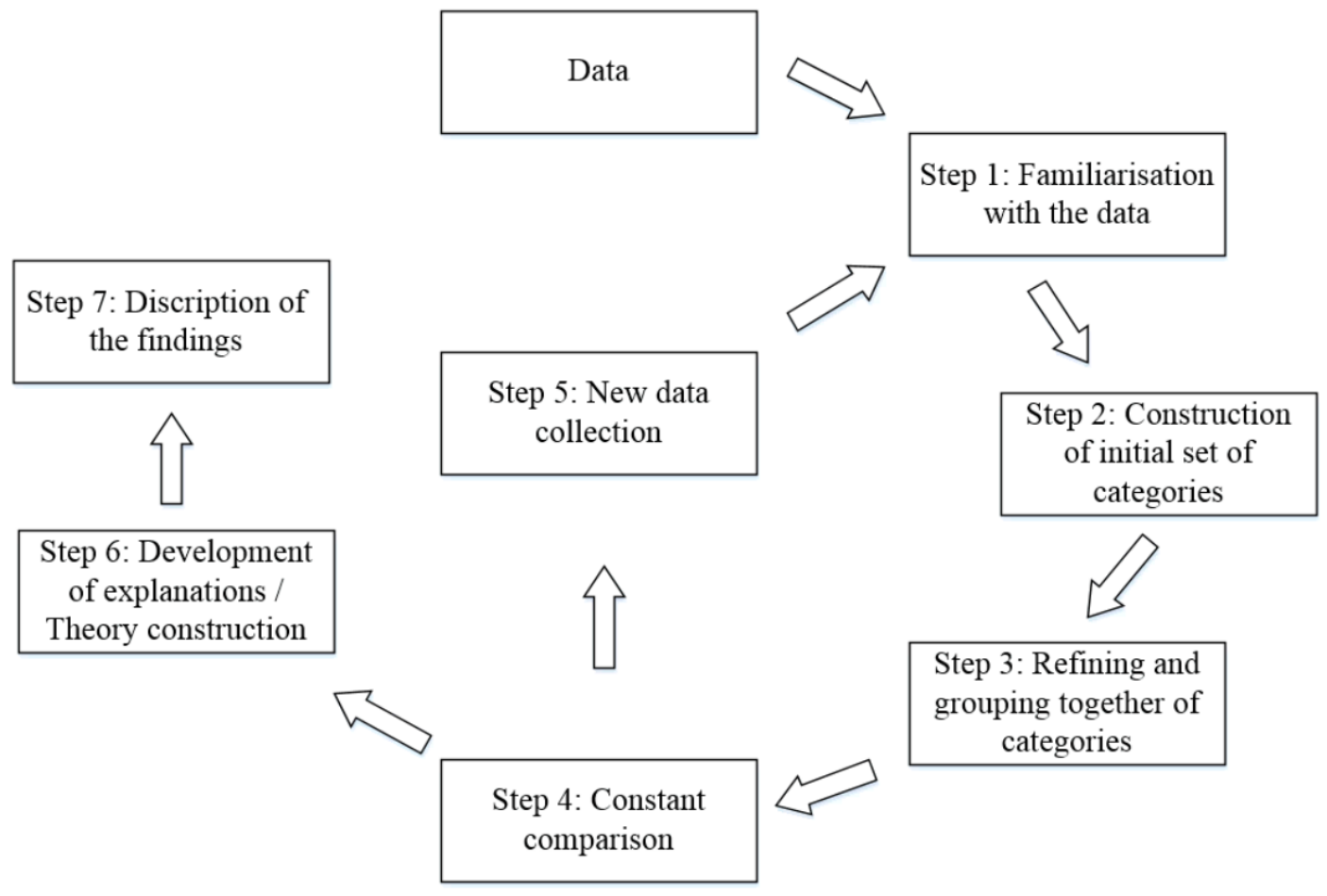

The analysis its aim is to identify conceptual categories or themes within data relating to the phenomenon of interest, so that those concepts can be used to develop a theory.

After reading the text through line by line, the first collected data were coded. Each useful text fragment was provided with a characteristic description, which is relevant for answering the question with the goal of achieving a reduction of the material that needs to be analysed more thoroughly. Every label must contribute in providing information about the phenomenon of financial fake news and/or the role the research unit plays in this (Baarda et al., 2013). Charmaz (2014) distinguishes three types of data coding: 1) initial coding; 2) focused coding; and 3) theoretical coding. Initial coding is the identification of an initial set of categories (the second step in Figure 3). Focused coding is the identification of relations between categories, so that the initial set of categories can be refined and emerging core categories can be identified (the third step in Figure 3). To conclude, theoretical coding is the saturation of the core categories identified (the third step in Figure 3). These 'steps of coding' were applied in the order of sequence mentioned above (Charmaz, 2014). In the fourth step, categories were continuously refined as a result of new insights from new data collected (the fifth step in Figure 3). Steps one to five are repeated until sufficient information is gathered to develop the conceptual model (the sixth step in Figure 3) and answer the research question (the seventh step in Figure 3).

The first author conducts all steps. The codes were created by using gerunds to contribute to the action and meaning embedded in the interviewees' responses (Charmaz, 2014). The coding schemes can be found in the appendix

\section{THEORETICAL FRAMEWORK}

In this section, the operational research questions are embedded in existing literature. In the first paragraph, it will be explained what is exactly meant by 'financial fake news' in this study. Thereafter, a guiding theoretical framework will be provided from which the dissemination of 
financial fake news can be constructed on the various levels explored. Finally, the role of the controller within the firm, which the available literature currently provides, will be described. This way, a theoretical base will be provided for the development of the sensitizing concepts $^{8}$ (Bowen, 2006; Charmaz, 2014).

\section{Financial fake news defined}

This paragraph focuses on defining financial fake news and elaborates on the sensitizing concepts 'the underlying philosophy of people in processing financial fake news' and 'the source of financial fake news'. This is will done by the following approach: first, the philosophies underpinning 'truth' will be explained since the absence of knowing the 'truth' is essential in considering fake news as real news. Then, the definitions in existing literature will be discussed in the following sub paragraph. Subsequently, a definition that fits within the context of this study will be formulated in the last sub paragraph.

\section{Philosophies underpinning 'truth'}

When knowing the facts, one can distinguish between real news and fake news under the empirical assumption that sufficient expertise is available to make the correct distinction. But when is a fact actually true and not false? This is a fundamental question that needs to be answered in order to define financial fake news, and that several philosophical movements aim to answer. To begin with, this question is also central to the strong programme of philosophy of science, which is characterised by a social constructivist view of scientific knowledge and proposes that both 'true' and 'false' scientific facts should be treated in a similar manner (Bloor, 1989; De Vrieze, 2018). Proponents of this theory question scientific facts through arguing that these facts are not a direct reflection, but a description of reality that has been realised through a combination of all kinds of irrational factors, such as bias, self-interest and group behaviour (De Vrieze, 2018). These irrational factors are considered wrong intentions for disseminating financial fake news.

The acknowledgement of a fact involves complex judgements and is, therefore, commonly questionable (Bloor, 1989). It can be said that this way of thinking is based upon the ideas of Latour and Woolgar regarding the construction of scientific facts (De Vrieze, 2018) as they stated that "A fact only becomes such when it loses all temporal qualifications and becomes incorporated into a large body of knowledge drawn upon by others" (Latour \& Woolgar, 1986, p.106). According to Salinas (2016), pragmatism plays a main role in Latour his ontology ${ }^{9}$. As much division exists around the meaning of pragmatism within this philosophical movement, this study also examines the philosophies of Peirce and James, who can be seen as founders of pragmatism. Peirce discussed on the nature of truth and knowledge and considered pragmatism as a method to clarify, by using logic, all sorts of concepts (Peirce, 1877), while James applied Peirce's pragmatism to his conception that a view is made true by events (James, 1907). James' conception of truth is explicitly taken into consideration for this section, since the adjective 'truth' underlies the definition of fake news. According to James (1907), "True ideas are those that we can validate, corroborate and verify. False ideas are those that we cannot" (p. 142) meaning that truth is made in the course of experience. To return to the empirical assumption that was made at the beginning of this section, the claim of experience as a source of knowledge contradicts rationalism. In epistemology ${ }^{10}$, rationalism holds that at least some human knowledge is gained through insights that are gained prior to experience, given that reality contains an inherently reasonable and logical structure (Blanshard, n.d.). By

\footnotetext{
${ }^{8}$ As mentioned in Section 2.2 .

${ }^{9}$ The philosophical study of the nature and relations of being, becoming or existence (Encylco, n.d.).

10 The philosophical study of the nature, origin, and limits of human knowledge (Stroll \& Martinich, n.d.).
} 
using the mind one can come to knowledge of the truth and thereby identify news as fake or real.

\section{Definitions used in existing literature}

There are several definitions of a controller in the existing literature. Allcot \& Gentzkow (2017) define fake news as "news articles that are intentionally and verifiably false, and could mislead readers", or in other words as "false stories" (p. 213). They conceptualise fake news as distorted signals, which are uncorrelated with the truth (Allcot \& Gentzkow, 2017). Keersmaecker \& Roets (2017) consider fake news as false information that has been disseminated for personal or political gains. According to Rubin, Chen and Conroy (2015), fake news is deceptive news that may be misleading and/or harmful. Fake does not necessary be disconnected from its original context and source. The task of fake news detection is defined by Rubin et al. (2015) as "the prediction of the chances of a particular news article (news report, editorial, expose, etc.) being intentionally deceptive (fake, fabricated, staged news, or a hoax)" (p. 1). Orwell (1946) described the vague and meaningless use of language as a characteristic of that intentional deceptiveness. He already warned in 1946 that language is "designed to make lies sound truthful and murder respectable, and to give an appearance of solidity to pure wind" (p. 264).

Rubin et al. (2015) separate three types of fake news: serious fabrications, large-scale hoaxes and humorous fakes. Fraudulent reporting, fraudulent journalistic writing, unverified news and exaggerations fall under serious fabrications. Deliberate fabrications and falsification fall under large-scale hoaxes and may cause material loss or harm to its audience. News satire and parodies fall under humorous fakes (Rubin et al., 2015).

In this study, serious fabrications and large-scale hoaxes will in the first place be considered as fake news. Furthermore, humorous fakes are not taken into account, as they can generally be distinguished as fake news by society due its feature of exaggerated reporting. However, fraudulent reporting will also be considered as fake news under the assumption that it is intentionally produced from within the firm. After all, the focus in this study is on fake news that is disseminated by sources from the inside as well as from the outside of the firm. Finally, conspiracy theories will not be considered as it is complicated to verify whether they are incorrect or not (Allcot \& Gentzkow, 2017).

Other common used terms, which are closely related to fake news, are 'rumours', 'false information' and 'misleading information'. Since false and misleading information are already part of above mentioned definitions, only 'rumours' will be considered. Kimmel (2010) focuses specifically on rumours in the financial market, which are caused by the dissemination of unverified and questionable information. Jia et al. (2017) also focus on rumours, in particular on negative rumours. They define rumours as "one or more news reports that a target firm denies through one or more official clarification announcements" (Jia et al., 2017, p. 1). Since rumours have the same meaning as false news, it can be seen as another term for fake news. Hence, the term fake news will be used in this study.

To conclude, Digital Shadows (2017) mentioned in their recent study on disinformation three motives for disseminating disinformation: 1) geopolitical, 2) ideological, and, 3) financial motives. Geopolitical and ideological motives are not necessarily aimed at financially harming the firm. Both motives consequently concern non-financial aspects and are relatively more aimed at influencing public opinion (Digital Shadows, 2017). Therefore, they are not included in the definition of financial fake news. 


\section{Definition used in this study}

When above-mentioned considerations are taken into account, the definition rules out several close related meanings: 1) news satires and parodies, and, 2) conspiracy theories. Furthermore, the definition relates to fake news that is disseminated because of financial motives. It has therefore been decided to use the term 'financial fake news' instead of 'fake news'. Finally, it can be concluded that fake news not necessary misleads its reader.

On the basis of the considerations described on the previous page, 'financial fake news' will be defined as: Unverified information about a firm that is intentionally false and could mislead its readers for financial reasons.

'Financial fake news' differs from the more general 'fake news' on its ultimate goal. This study assumes that financial motives are the main reason for disseminating financial fake news and influencing the public opinion is of less importance. In the case of 'fake news', the dissemination can include both financial motives and the influencing of the public opinion (i.e. market manipulation). 'Fake news' thus includes, amongst others, 'financial fake news', and hence is the umbrella term for unverified information that is intentionally false and could mislead its readers for all reasons.

\section{Systems Theory}

Systems thinking originates from the Systems Theory (Weinberg, 1975) and complements to analytical thinking from a systemic perspective by providing "a way of looking at how the world that differs markedly from the traditional reductionist, analytic view" (Kim, 1999, p. 1). It also enables to form a well-rounded problem description resulting in conceptually rich narratives (Boardman \& Sauser, 2013; Charmaz, 2014). These principles of the Systems Theory, and specifically systems thinking, are chosen to embed in this study as a sensitizing concept because of three interrelated motives. First, the impact of financial fake news increases and needs to be countered (Kimmel, 2010; Kuchler, 2017). As long as financial fake news exists, there is a 'systemic' failure when counteracting financial fake news in terms of systems thinking (Boardman \& Sauser, 2013). A research focus on the systemic aspect of the phenomenon of fake news is therefore of importance. Second, financial fake news evolves as a result of the rapidly changing world. Thus, a system-wise view is of added value to fully understand the phenomenon of fake news, because it complements with analytical thinking (Kim, 1999). Third, in this event-orientated world, events, such as the occurrence of financial fake news, are being more easily noticed compared to patterns and systemic structures even though these events are driven by systems and, thus, are "results of deeper patterns and systemic structures" (Kim, 1999, p. 4). As mentioned by Kim (1999), this tendency to focus on events is conform evolutionary biology, which was geared towards reacting to immediate dangers to human's well-being. In order to counteract financial fake news effectively, measures aimed at improving the management of deeper patterns and systemic structures are required. Furthermore, analysing phenomena at a systemic level provides more leverage to shape future directions than solely analysing events does (Kim, 1999). Next to that, when there is a clear understanding of the systems behind emerge of financial fake news, the processes of improving quality of life can be continued while the negative effects can be reduced (Boardman \& Sauser, 2013). As Boardman and Sauser (2013) assert: "A better understanding of the worlds of systems will lead us more assuredly to a knowledge of the truth" (p. 34).

Overall, the Systems Theory aims to enhance the researcher's knowledge of possible relations between the actors in this study. This way, conceptually rich narratives can be developed, which is in line with the constructivist GTM (Charmaz, 2014). This study, and especially the 
development of the conceptual model, is therefore guided by the Systems Theory in the fifth section.

\section{Role of the controller}

In this paragraph, the role of the controller within a firm will be elucidated based on existing literature. The definition that will be used in this study, the evolution of the controller profession and several roles based on the nature of work will be addressed.

There are several definitions of the controller, otherwise called management accountant, in existing literature. Zimmerman (2005) formulated the controller as "the person in charge of both management and financial accounting in an organization" (p. 784). De Loo et al. (2011) used in their study the following definition: "A controller supports and advises the management of an organization in realizing their economic, public and / or financial goals" (p. 11). They interpret 'support' in terms of "the design and maintenance of management control and accounting information systems, and the procurement and distribution of information" (De Loo et al., 2011). Another approach in defining the controller is to divide its role into three elements as Sathe (1982) did by referring to someone who supports the management team in the decision-making process, ensures the integrity of the provided financial information within the firm and monitors the internal procedures. In this study, the definition of Sathe et al. (1982) will be used as it includes the definitions of Zimmerman (2005) and De Loo et al. (2011).

In the past decades, the role of the controller has changed to comply with the firms' changing needs as a result of globalisation and the increasingly changing markets (Strikwerda, 2008). According to Granlund and Lukka (1998), the controller function has shifted from a more administrative controlling focus to a more advisory role, which indicates a growing recognition for the controller his business acumen and strategic outlook (Ten Rouwelaar, 2006). Oostdijk and Zwiep (2014) therefore state that the controller of the future will be more businessorientated. Where the business controller is increasingly focusing on advising the management, the financial controller is increasingly moving towards business intelligence tasks (Oostdijk \& Zwiep, 2014). Also, an increasing focus on value creation broadens the role of the financial controller (Ernst \& Young LLP, 2011). In this respect, it is assumed that this shifting focus of required skills and responsibilities offers room for the controller in contributing to the decision-making regarding financial fake news. However, many other roles of the controller are mentioned in existing literature, varying from scorekeeper to watchmen (Simon, Guetskow \& Kozmetsky, 1954; Sathe, 1983; Jablonsky \& Barsky, 2000; Maas, 2005; De Loo et al., 2011). An overview of the possible functions for a controller regarding the counteracting of fake news is therefore given in table below: 


\section{Table 2 : Literature overview of the roles of the controller based on the nature of work}

\begin{tabular}{|l|l|l|}
\hline \multirow{2}{*}{ Author } & Role & Focus within the nature of work \\
\hline \multirow{3}{*}{ Sathe (1983) et al. (1954) } & Scorekeeper & Compliance reporting \\
\cline { 2 - 3 } & Attention director & Control-type issues \\
\cline { 2 - 3 } & Problem solver & Management-support \\
\cline { 2 - 3 } & Involved controller & Management-support \\
\cline { 2 - 3 } & Splependent controller & Internal control and financial reporting \\
\cline { 2 - 3 } & Strong controller & $\begin{array}{l}\text { Responsibilities for management service, internal } \\
\text { control and financial reporting are assigned to } \\
\text { different persons. }\end{array}$ \\
\hline \multirow{2}{*}{$\begin{array}{l}\text { Jablonsky \& } \\
\text { Barsky (2000) }\end{array}$} & $\begin{array}{l}\text { Responsibilities for management service, internal } \\
\text { control and financial reporting are assigned to one } \\
\text { person. }\end{array}$ \\
\hline Maas (2005) & Corporate policeman & $\begin{array}{l}\text { Financial reporting and enforcing compliance with } \\
\text { policies and procedures }\end{array}$ \\
\cline { 2 - 3 } & Business advocate & $\begin{array}{l}\text { Financial reporting, maintaining cross-functional } \\
\text { relations with others and management-support }\end{array}$ \\
\hline \multirow{2}{*}{$\begin{array}{l}\text { De Loo et al. } \\
\text { (2011) }\end{array}$} & Trust role & $\begin{array}{l}\text { Responsibility for correct, complete and timely } \\
\text { financial reporting }\end{array}$ \\
\cline { 2 - 3 } & Supervisory role & Supervision of employees' actions \\
\cline { 2 - 3 } & Management-service role & Management-support \\
\cline { 2 - 3 } & Information adopter & Organisational needs and change processes \\
\hline
\end{tabular}

As can be derived from the table, the controller plays a multidimensional role within the firm. Hence, the role of the controller depends on its range of duties: whether he only performs administrative tasks, or is also involved in the controlling and decision making process (Riedijk, Tillema \& Moen, 2002). In the absence of existing literature on the subject of roles that can be assigned to the controller in counteracting financial fake news, the roles presented in the table only serve as sensitizing concept for answering the fifth research question in Section 5. In addition, a thorough explication of all displayed roles exceeds the scope of this study as it aims to build a theory.

\section{Summary}

As mentioned in Section 1.4, there is little to no evidence about the role of financial fake news in existing literature. The sensitizing concepts ${ }^{11}$ covered in this theoretical framework therefore serve as a basis for developing the conceptual model on the phenomenon of financial fake news. At the start of this chapter, financial fake news is defined as "unverified information about a firm that is intentionally false and could mislead its readers for financial reasons". Thereafter, literature research was conducted into the Systems Theory, a theory that contributes to the exploration of the phenomenon through analysing this study's results, where possible, in a system-wise way. Since this system-wise view complements with analytical thinking, it contributes to a better understanding of the phenomenon of fake news. Finally, the role of the controller in the existing literature was investigated. The existing literature shows multiple roles of the controller depending on the controller's range of duties. In order to be able to investigate where within those described roles the counteracting of financial fake news can be placed, an overview of the roles is given.

11 Sensitizing concepts provide a theoretical base for its development, indicate the direction in which the researcher must look to answer the research question and can thus be seen as a starting point for a qualitative study (Bowen, 2006; Charmaz, 2014). 


\section{RESULTS}

This section will present the collected data from interviews and observations, on the basis of which the conceptual model will be designed. Each paragraph will represent a level, following a top down approach in answering the research question. Since the use of quotations is widely recognised in qualitative research, descriptive passages about the results will be substantiated with quotations (Ritchie \& Lewis, 2013). This way, the current state of the fight against (financial) fake news at the different levels will be explored. Since 'fake news' was generally discussed more frequently during the interviews, it needs to be remarked that 'fake news' as well as 'financial fake news' will be considered for the remainder of this report.

\section{Overall level}

The collected data indicate that the interviewees have different perceptions of the meaning of fake news, since there is no univocal understanding of fake news. Quotes such as "What is the definition of fake news?", "When something fake news is and when it is not? I do not know" and "It is a very broad concept I think" show the prevailing uncertainty among the interviewees about the meaning of fake news. It is also questioned when news can be considered as fake, as shown by the following excerpt:

"We often see that people misuse certain arguments in order to convey their point of view. A point of view about an event, is that fake news? I do not think so myself. I think it is a bit of a grey area when something is really fake news and when incorrect arguments are used in a discussion." - Controller $2^{12}$

In addition, the interview data show various forms of fake news. First, it can be distributed from the outside, but also by the firm itself. Second, fake news can be distributed by the established journalistic order, by random individuals or by competitors of a firm. Third, fake news appears in different gradations ranging from close to the truth to far from the truth, as mentioned by the expert in reputation and communication. Finally, it can be distributed in the form of a news item, but it may also involve financial inaccurate figures about the firm. There is no clear definition from a societal and legal perspective, as indicated by the expert in IT and Internet law. The lack of a definition of fake news so far exists in his view due to the absence of taking situations into consideration in which people deliberately make legitimate looking news that are actually fake, as is shown by the excerpt on the following page.

"There have always been people who proclaimed lies, but they did not go through the filter of newspaper or television. And a newspaper that disseminates a false message rectified it. This happened usually voluntarily, otherwise through the courts. Or it turned out to be a joke and then we laughed about it. However, this situation is new: fake news that is presented as completely real, and not even an attempt to rank it under satire." - Expert in IT in internet law

The lack of a clear definition is also apparent from different terms that were used by the interviewees, such as 'Demagoguery', 'Falsehoods', 'Disinformation', 'Untruths', 'Alternative facts' and 'False, incorrect or misleading information'. According to the chairman of the Dutch Press Council ${ }^{13}$ and also former journalist, 'fake news' is frequently used in the news as it sounds better, and also, making the news items more attractive to read it. He also indicates that the valuation of reliable information increases as the awareness of the impact and damage of

\footnotetext{
12 To ensure secrecy, some interviewees will be randomly labelled, for instance as Controller 2.

13 The Dutch Press Council is "charged with the examination of complaints against violations of good journalistic practice" (Raad voor de Journalistiek, n.d.).
} 
fake news increases. Likewise, more people are becoming worried about fake news as the following quote shows:

"I hope that the increased familiarity with the phenomenon of fake news will lead to more people thinking about it, not only in journalism, but also in education, in politics, in society and so on. That would be the best outcome. I think that we may have been uncritical for too long in the news we receive, also from online sources, by assuming that it is all correct." - Chairman of the Dutch Press Council and former journalist

\section{Society level}

Two Dutch authorities were questioned about what they do to counteract the dissemination of fake news: the Dutch Authority for the Financial Markets ('AFM') ${ }^{14}$ and The Dutch Press Council.

A regulator of the AFM indicates that they regularly come across parties that provide incorrect information to investors. This concern, for instance, investment projects financed with investors' money and investment projects that do not exist or are less favourable than predicted. In many of these cases there is also investment fraud, which receives attention from the Netherlands Public Prosecution Service ${ }^{15}$ and the FIOD ${ }^{16}$. In such cases, the role of the AFM can be to communicate the essential information to individuals or to oblige a disseminator of fake news to correct it. This often involves investments that are exempted from the Financial Supervision Act ${ }^{17}$, so that the AFM can only intervene after the damage was already caused. In those cases, fake news occurs in the form of an incorrect information memorandum ${ }^{18}$ or incorrect newsletters, for instance about the course of an investment project. To conclude, fake news also occurred in the boiler rooms fraud ${ }^{19}$, as explained in the following excerpt:

"We observed that boiler rooms set up fake websites that resemble real-world websites and spread fake news about fake stocks through those websites. The AFM explicitly warned about this form of fake news this year." - Regulator of the AFM

The Dutch Press Council, on the other hand, only handles journalists' publications. According to the chairman of the Dutch Press Council, they mainly consider whether journalists comply with certain codes of conduct, such as the use of hearing and rebuttal, the truth and privacy protection. Whether a message is true or less true receives less attention by them. Accordingly, the chairman was also asked about his opinion about fake news. He states that critical readers must be able to verify the news themselves. To enable this, journalists must be able to demonstrate why their reporting is correct, as explained by the following excerpt:

"The problem, I think, is that many reports are correct, but there is a continual demand for new reports from certain websites. When selecting and evaluating these reports, there is often a lack of time to evaluate and verify the validity of the facts. I also understand that it happens under time pressure and the pressure to attract more visitors, but in the end, I hope that visitors will also be more aware of the differences between sources meaning that good sources

\footnotetext{
14 The AFM is responsible for supervising the operation of the financial markets (AFM, n.d.).

15 In Dutch: 'het Openbaar Ministerie'.

16 FIOD, the tax intelligence and investigation service of the Dutch tax authorities.

17 In Dutch: 'Wet op het financieel toezicht'. This act brings together a large number of rules and regulations for the financial markets and its supervision.

18 Sometimes referred to as a prospectus, but in that case it is not previously approved by the AFM.

${ }^{19} \mathrm{~A}$ form of investment fraud that is usually carried out from a location abroad from where the fraudsters approach potential investors by telephone with a false investment offer (usually non-existing shares).
} 
exist, but also less good sources. As a journalistic medium you can only try to show that you are reliable by being very transparent about your working method. Moreover, the journalist must take responsibility, even afterwards, if problems occur. This way, a journalist can convince readers that he or she has to be taken more seriously than other sources." - Chairman of the Dutch Press Council and former journalist

This is, however, one opinion about who is responsible for counteracting fake news. The other interviewees also referred to social media platforms, the government, legislators, firms, and individuals as the ones being responsible.

\section{Segmental level}

In this section, the question how fake news is positioned within the segment of large firms will be answered. In doing so, the influence of the firm size and firm type on the position of fake news in the firm's policy are considered.

First, alertness to events in the market is mentioned as an important task for large firms because of their prominent role in the market, as illustrated by the following excerpt:

"What we have to deal with, of course, is that we are a market player. This means that you have to take into account what is happening in the market. There may be signals from the market to which you have to respond, given the fact that a risk may occur if you do not respond in the right way." - Controller 1

Large firms do, however, have their own Communication Department, which is quoted by the interviewees as one that plays an important role in countering fake news. The department monitors the reporting about its firm, as the following excerpt addresses:

"They keep an eye on how the public discussion develops and what arguments are used. They also often make an assessment of whether we react to something or come up with a specific story line about a certain theme." - Controller 2

The Communication Department reports fake news that is being disseminated about the firm and reports it to its immediate supervisors when necessary. In the case of serious allegations with a major impact, the management becomes also involved, as illustrated in the excerpt below:

"It is of course the case that within our firm and that will be the case with every firm, that we have a Communication Department. They also follow the news on all kinds of websites such as Twitter, Facebook and so on. If all sorts of inaccuracies occur about our firm, they will also signal this from their position, when required, to the Management." - Controller 4

Large firms, in general, also have more options and capital available to analyse and counteract fake news, which is illustrated by the excerpt below.

"We have departments such as external relations that analyse the market. In fact, I think that larger firms have more capacities to monitor developments in the market than smaller firms. Then you can temporarily deploy some employees who perform these data analyses. You are able to discover consistencies faster due to having more computing capacity available." Controller 3 
On the other side, large firms can also indirectly contribute to the creation of fake news through their activities. In the pursuit of certain interests, agreements can be made behind the scenes with other parties. The news that is subsequently announced about those agreements made may not reveal the real motives. The question is when this concerns fake news, as Controller 3 mentioned: "I think a lot is being manipulated, lobbied and done. When is something fake news and when not? I do not know".

Finally, fake news incidents barely influence business valuations policy when the firm is longterm oriented, as illustrated by the following excerpt:

"Essential news, which always can be fake, does not indirectly result in us changing our policy. This type of day-to-day news is monitored, but we value it in the long term. At a certain moment, short and long-term issues do balance out." - Controller 3

\section{Firm level}

In this chapter, results concerning the dissemination, proactive countermeasures, reactive countermeasures and outsourcing of risk control on firm level are elaborated.

The dissemination of fake news has increased with the introduction of the Internet and social media in particular, as assumed by Controller 2 and the expert in reputation and communication. Moreover, there is uncertainty amongst the interviewees about the number of fake news disseminated about the firm as they often answered with terms such as "I think" and "presumably" and "I cannot prove that."

Another result is that most interviewees do not see fake news as a threat to the firm's reputation, since they do not think a lot of fake news is being disseminated about their firms as, for instance, mentioned by Controller 1: "I do not think that we are affected that much by fake news." Also, the number of people who intentionally distribute fake news to cause harm to the firm is, in their view, limited. According to Controller 1, it are rather people who do not deliberately disseminate fake news, but are simply not well informed about the facts, which is a nuance difference that the firm and its employees have to deal with. Controller 4 his experience corresponds to this, as he does not come across fake news that is knowingly and intentionally disseminated about the firm, but rather across news that completely lacks context or nuance. On the contrary, it emerged from an enquiry to the AFM that the fake news they have encountered so far is in many cases preconceived and thus no mistake or error.

When counteracting to fake news, commonly mentioned during the interviews is the firms' aim to strive for that same transparency to counteract fake news, as Controller 4 mentioned: "It is always the challenge to respond to the situation in the best way." Thereby, he refers to transparency and states that the reaction of the firm on the fake news should be in line with the language that readers understand. This way, firms can counteract fake news. In addition, Controller 2 points out that it must be done accurately as "the fight against fake news can also lead to fake news." Controller 5 aligns with this as he asserted, "Only well-thought-out news should be published by firms." Controller 3 shares their opinions as he states the following:

"I think the best way is to simply create as much openness and transparency as possible, while ensuring that the information is available to the various sources. This way, there is more "real news" and people can draw their own conclusions from it." - Controller 3

From the legal point of view, an expert in IT and internet law indicates that it is difficult for firms to counteract fake news, because legally there is no clear definition of fake news. He 
substantiates this by the stating: "If you do not know what it is, you can hardly make it punishable."

Various reactions came to the question of the extent to which firms can prevent the publication of fake news about their firm. Some interviewees believe that only reactive actions are possible, while others think that preventive actions definitely do have a role to play in counteracting the dissemination of fake news. On the one hand, monitoring what is being said about the firm on the Internet, keeping yourself informed about the developments in the market and reacting with actual facts are commonly mentioned reactive measures. On the other hand, firms can prevent fake news to a certain level by proactively communicating about very sensitive topics that could qualify for fake news in advance, as pointed out by Controller 4. However, Controller 5 stated that the firm "cannot anticipate on everything because they do not always know who the disseminator is". The expert in reputation and communication aligns with this as he states: "I think you can only prevent it to a limited extent, but I do think it is possible to ensure people are having a good image of firm."

Finally, the interviewees indicated that the firms are not outsourcing the control of risks that are arising from fake news. This align with the results of the enquiries made with ten consultancy firms in the field of reputation management, crisis management, communication and corporate affairs, since those results reveal that fake news includes a small portion of their activities.

\section{Function level}

The interview data show that there is no clarity about the role of the controller in counteracting fake news. The controller is mentioned as one that plays no role, a limited role or does certainly play a role. According to Controller 1 and 3 , it is mainly the function of the Communication Department and not a core activity of the controller. According to Controller 5, it just depends on how wide the task of the controller is considered, as he explains in the excerpt below:

"At the moment that there is reputation damage attached to it, I think it is their job to get involved. From a common sense perspective, I say of course the controller should interfere. From the working field as well, because he has to see what happens to the firm and to what extent fake news can influence the firm's policy or strategy." - Controller 5

However, Controller 4 stated that the controller does certainly play a role in countering fake news, but just not a pivotal one. He substantiated it by the nature of the controlling profession, as the following excerpt shows:

"As a controller, you are concerned about the reliability of the firm's information provision by constantly looking for the correct and complete information. So it is certainly part of the controller that you counter fake news by ensuring that all the facts are on the table, which is inherently the opposite of fake news." - Controller 4

As the above excerpt shows, Controller 4 links the phenomenon of fake news to the responsibility of the controller in the context of the reliability of the information provision. Regarding the direct involvement of controllers in drawing up financial statements and the phenomenon of fake news, he states the following:

"Fake news that is disseminated by sources from outside the firm is not an active part of my role, but of our Communication Department. They have the 
task to respond immediately. But the controller does have a role in ensuring the accuracy and completeness of the financial statements. The controller draws up the annual accounts, reads the annual report and checks for facts and inaccuracies. These tasks and responsibilities can be linked to the phenomenon of fake news." - Controller 4

The Communication Department continuously monitors what is written about the firm on the Internet and mainly on social media. If there are inaccuracies, they will be the first to signal this. However, as explained by Controller 4, when you talk about the specific control products where a controller is involved, then he or she has the task to guarantee the reliability by always looking at the actual facts. Specific control products are in this case the entire integral business information provision and all of its facets, such as the financial statements or a SWOT-analysis during a strategy session. In relation to counteracting fake news, the controller essentially plays the following role:

"As a controller, you are the (business-economic) conscience of the firm, and my vision would be that as a business-economic conscience you should also ensure that the reliability, correctness, completeness and, of course, current affairs are assured for all business economic issues in the business information provision." Controller 4

Part of that role is to cover the risk of market manipulation, as described in the following excerpt:

"We have designed our control framework in such a way that we know for certain that we as a firm, and perhaps also as individual traders, will not manipulate the market. It may have a bit to do with fake news when another firm, a competitor, might give wrong signals for their own purposes." Controller 1

In that sense, all parties involved cooperate in counteracting fake news as effectively as possible. However, it still remains a challenge to react in a timely and correct manner due to the uncertainties that fake news entails.

\section{DISCUSSION AND CONCLUSION}

The aim of this study is gain a fundamental understanding of the phenomenon of financial fake news. To develop that understanding, this study explored the phenomenon on five levels of analysis. In this section, the findings concerning the results will be elucidated in the first paragraph and discussed in the second paragraph. Based on the presented findings, the report's main conclusions will be drawn in third paragraph. This way, the theory developed in the conceptual model will be built up further on the basis of existing literature. Thereafter, the implications will be explained in the fourth paragraph and the limitations in fifth paragraph. Future research directions and recommendations for practice will be given in the sixth paragraph, followed by the closing words in the seventh paragraph.

\section{Findings}

To give an overview of the findings of this study, the different levels of exploration are interrelated through interconnecting the results from mainly the interviews, but also from observations and literature study. This is achieved by identifying and saturating core categories based on the identified initial codes for the five sub-questions (see appendix). The findings made are presented in Figure 3 in the form of a constructivist-interpretative conceptual model, in which the emphasis is on characteristics, actions, and processes around constructed concepts: 
Figure 3: Conceptual model about the dissemination and mitigation of (financial) fake news

\begin{tabular}{|c|c|c|c|c|}
\hline & \multicolumn{3}{|c|}{ The dissemination and mitigation of (financial) fake news } & \\
\hline $\begin{array}{c}\text { Overall level: } \\
\text { No univocal } \\
\text { understanding of the } \\
\text { phenomenon of fake } \\
\text { news }\end{array}$ & $\begin{array}{l}\text { Society level: } \\
\text { The task of } \\
\text { counteracting fake } \\
\text { news lies with all } \\
\text { parties involved }\end{array}$ & \begin{tabular}{|c|} 
Segmental level: \\
Large firms have a \\
specialised approach in \\
counteracting fake \\
news
\end{tabular} & \begin{tabular}{|c|} 
Firm level: \\
Firm specific approach \\
in counteracting the \\
specific cases of fake \\
news
\end{tabular} & $\begin{array}{l}\text { Function level: } \\
\text { The controller as the } \\
\text { business-economic } \\
\text { conscience of the firm }\end{array}$ \\
\hline \begin{tabular}{|l} 
Various forms of \\
fake news \\
- Various motives for \\
spreading fake news \\
- No clear definition \\
- Prevailing uncertainty \\
about the meaning of \\
fake news \\
Ignorance about \\
certain features of \\
the phenomenon of \\
fake news
\end{tabular} & $\begin{array}{l}\text { The AFM and Dutch } \\
\text { Press Council apply } \\
\text { corrective } \\
\text { countermeasures to } \\
\text { cover Dutch citizens } \\
\text { against fake news. } \\
\text { - Increasing awareness } \\
\text { for the phenomenon of } \\
\text { fake news } \\
\text { Different } \\
\text { perspectives about } \\
\text { who is responsible } \\
\text { for counteracting } \\
\text { fake news }\end{array}$ & \begin{tabular}{|l} 
- Brand awareness \\
- More options and \\
capital available for \\
analysing and \\
counteracting fake \\
news \\
- The Communication \\
Department plays an \\
important role in \\
counteracting fake \\
news \\
Discrepancy \\
between types of \\
firms in approaching \\
fake news
\end{tabular} & \begin{tabular}{|l} 
- Uncertainty about \\
the impact and \\
frequency of fake \\
news \\
- Uncertainty about \\
the deliberate \\
damage motive of \\
fake news \\
- Context specific \\
- Transparant and \\
accessible \\
Different \\
circumstances under \\
which fake news can \\
occur
\end{tabular} & \begin{tabular}{|l} 
- Ensuring reliability, \\
accuracy, \\
correctness, \\
completness and \\
current affairs for all \\
business economic \\
issues in the \\
business information \\
provison. \\
Decision-making \\
and monitoring role \\
Broad versus more \\
narrowly orientated \\
controllers \\
No clarity about the \\
role of the controller \\
in counteracting \\
fake news
\end{tabular} \\
\hline
\end{tabular}

This conceptual model argues that, on each level of exploration, different characteristics influence the approaches in counteracting (financial) fake news. The conceptual model on the previous page is more descriptive rather than normative as it describes the current situation in counteracting fake news. The columns represent the answers to each sub-question in ascending order, where the main findings shown in the squares are derived from a combination of the findings below each square. Following the inductive approach in answering the main question, all five columns contribute to answering the main question by providing insights into the role of the controller within the general situation of counteracting fake news. It is found that the controller plays a multidimensional role within the firm depending on its orientation, the type of fake news, the type of the firm and its related tasks. When looking specifically at the role of the controller in counteracting the dissemination of financial fake news, the findings indicate that the role of controllers is embedded in its professional scepticism $^{20}$, as they are the business-economic conscience of the firm. Part of this role is being vigilant in recognising financial fake news and its related risks. In addition, the results indicate that being sceptic in a professional way does also apply to society, firms and individuals.

\section{Discussion of findings}

As indicated by the presented findings, fake news in general and financial fake news specifically can be defined in different ways depending on the context and focus of interest. Part of the detected increasing awareness for the phenomenon is the emphasis on the readers' ability to verify the integrity of information, which aligns with the rationalist belief ${ }^{21}$ that one can come to knowledge of the truth and thereby identify news as fake or real by using the mind (Blanshard, n.d.). Thus far, there is still ignorance about the phenomenon of interest, since the interview data show that the impact, size, motives and extent of the dissemination are

${ }^{20} \mathrm{An}$ attitude that includes a questioning mind, which is already of great importance in for instance the audit profession as the auditor must be alert that firms will not publish 'financial untruths' (IAASB, 2016).

21 As outlined in Section 3.1.1. 
commonly unknown. This prevailing uncertainty among the interviewees about the meaning of fake news aligns with existing literature considering philosophies underpinning 'truth' as they state that it is difficult to acknowledge a fact (Bloor, 1989). The absence of a general definition probably also affects the shifted focus to 'fake news' during the interviews despite the initial focus on 'financial fake news'. From these findings can be interpreted that financial fake news evokes confusion among individuals.

Since the two Dutch authorities that were questioned mentioned that they play a reactive role in counteracting fake news, it can be interpreted that individuals are initially dependent on themselves in recognising fake news. Taken earlier mentioned philosophies of Section 3.1.1 into account, fake news has its detrimental effect if its reader unjustly considers it as true. Thereby, individuals' ability to identify news as fake depends their knowledge about the topic, but is also influenced by the presence of opposing news sources. If, for instance, left wing and right wing media give corresponding reports, this could be regarded as truth. The source, which is not always known in the case of fake news, is thus essential. In the absence of this information, readers are dependent on their knowledge and reasoning ability alone. Nonetheless, the increasing awareness for the phenomenon of fake news may indicate an increasing alertness among individuals in recognising fake news.

When looking specifically at the position of financial fake news within the segment of large private firms, it can be interpreted as a two-folded position. On the one hand, large firms are forced to keep a close eye on fake news issues where necessary to safeguard their market position. On the other hand, they have the required resources to be able to do that. This raises the feeling that there is a general belief among large firms that they are well organised and shall not let themselves be beaten by this pernicious phenomenon. Although they have a reputation to lose, it seems as if they are not worried about whether they have sufficient capacity to counter fake news. The result that external consultants are not that much hired by firms concerning fake news issues may also be an indication of this self-image.

On the firm level, the results indicate that the dissemination and mitigation of fake news are dependent on the firm's approach. In doing so, firms usually only take action and hire external consultants when the impact can be high. Besides that, firms do not have a large range of legal options to counteract fake news. That, however, does not alter the finding that transparency is seen as the best practice in counteracting fake news by the interviewees. From this finding, it is interpreted that silence can have a reinforcing effect on fake news.

However, as illustrated by for instance Musk's SpaceX project ${ }^{22}$, it should be taken into account that there are two opposite variants of fake news: positive fake news and negative fake news (Pasztor, 2018). Those two camps emerged in response to Musk's statement that he is trying to build a fleet of rocket ships that are able to transport humans to Mars (Pasztor, 2018). The positive camp disseminates exaggeratedly positive news about the project, whereas the negative camp disseminates incorrect negative news. Positive fake news can attract ignorant investors, which raises the feeling that in case of positive fake news the incentive for firms to be transparent is lower than in case of negative fake news. The absence of a corrective statement by the firm can result in far-reaching consequences to society's general perception of the project. When positive fake news is adopted massively, the impact can be destructive. Crashes of economic bubbles can be interpreted as the result of many firms not pursuing

22 An American aerospace fabricator founded by Musk with the aim of reducing space transport expenses and enabling the colonisation of Mars (Pasztor, 2018). 
transparency ${ }^{23}$. Thus, the notion is that, fake news can have adverse consequences for some, while it can have beneficial consequences for others. However, the beneficial consequences can be of a temporary nature and turn into negative ones.

Another finding was that there is no unanimity among the interviewees about the deliberate damage motive of fake news, which does not align with existing literature that assumes a consciously dissemination of fake news (Rubin et al., 2015). This may be caused by an underestimation of the evil that underlies fake news. The result that external consultants are not that much hired by firms concerning fake news issues may also be an indication of this underestimation. It is therefore debatable that most firms are not subject to any fake news disseminated with the aim to deliberately cause damage to the target firm.

Finally, the controller being vigilant in recognising financial fake news and its related risks aligns with existing literature as the controller fulfils in this way the role as a problem solver (Simon et al., 1954), involved controller (Sathe, 1983), helper of the top management (Maas, 2005) and, mainly, a watchmen (De Loo et al., 2011). These roles include supporting the management and keeping the firm risks in control. In large firms, the attention for fake news can be allocated to the tasks pertaining to the respective roles. Despite the fact that large firms do have, in general, more capabilities for a better-attuned approach in counteracting fake news compared to smaller firms, it is still difficult to formulate a universal approach in counteracting fake news. After all, there is no univocal understanding of the phenomenon of fake news.

\section{Conclusion}

The underlying essence of the discussed findings seems to have its roots in discovering the truth. In Dutch democratic society, citizens are free to discover and determine the truth for themselves on the basis of all information they have at their disposal. The underlying process to discover the truth can be reflected by the paradoxical metaphor of Schrödinger's Cat $^{24}$ in which there is a situation of a cat that is placed in a sealed box along with a contraption that can kill the cat. In this setting, the real situation in the box is unknown to bystanders until the box is opened. As long as the box is unopened, the cat is 'both death and alive'. Since the cat cannot be both, it must be investigated what the real situation is (Schrödinger, 1935). This speculative setting is also the case with news (the cat) as it can be fake (dead), but also true (alive).

In the process of opening the box to discover the truth ${ }^{25}$, rational considerations are being made. These considerations are already embedded in the role of the controller as 'being the conscience of the firm', where conscience finds its origin in the inner awareness of good and evil and is one of the characteristics required for professional scepticism. The controller should hereby assert his inner voice, for which he needs to have the moral ability to critically assess his own actions. This entails an inner responsibility that should guide the controller in performing his profession and can be linked with his role in counteracting fake news. However, conscience is also formed by the social context in which the person finds himself, as is evident from Freud's psychoanalysis: The tension between the internalised "Über-Ich" (the 'imprinted'

\footnotetext{
${ }^{23}$ A well-known example is the dot-com bubble during the late nineties (Investopedia, n.d.).

${ }^{24}$ Hypothetical mind experiment about quantum physics with the aim to show that any scientific theory must be tested and proved before one can state it as true or false (Schrödinger, 1935).

25 With reference to Gödels incompleteness theorem, every statement is either incomplete (i.e. there are true statements that cannot be proven), or is inconsistent (i.e. there are false statements that can be proven), with the result that the discussion whether news is fake or not cannot be easily solved in a final way (Franzén, 2005).
} 
norms by society) and the emancipating "self-acting Ich" (1933). The controller's conscience is thus a combination of both inner character traits and situational characteristics. The latter includes prescribed rules and guidelines concerning the controlling profession such as training, organisational interests and codes of conduct. This is also reflected in the way in which the controller counteracts fake news and how much importance is assigned to that. The malleable situational element indicates the future possibility of a changing role lying ahead for the controller in counteracting fake news.

However, from an economic point of view, a noteworthy question is to what extent fake news needs to be countered when the harmful effects of phenomenon, as indicated by Smith's 'invisible hand', correct themselves (Smith, 1776). As demonstrated by the recent unregulated cryptocurrency world, fake news can have a major impact on prices when there are no protectionist interventions. ${ }^{26}$ This aligns with the views of proponents of Smith's theory stating that it is too simplified, as there are incomplete markets with an imperfect and asymmetrical information service (Stiglitz, 2018). The question is thus whether one should intervene or adopt a wait-and-see attitude until the 'invisible hand' corrects the fake news. Again, the rational considerations come into play. When is intervention necessary? Should one intervene to protect the potential victims of fake news from losing their money? Is it unethical to leave them to their fate? It is known that people do not always act as wisely as they should, which is why roundabouts have been constructed and civil liability insurances are required. Either way, logical considerations are also relevant, including the extent to which fake news disrupts the proper functioning of the market, the extent to which fake news can actually be counteracted and the extent to which fake news poses a threat to society and the economy. These are all complex issues related to the phenomenon that cannot be answered unambiguously.

After all, it can be said that fake news is a complex phenomenon that is rather an assessment or judgement than a measurable fact, whereby its complexity stems from the phenomenon's multidimensional characteristics and influences one's ability, resources and willingness to detect fake news. One will be better able to accomplish this than the other with the consequence that fake news cannot be fully counteracted, which indicates a common challenge for society to counteract fake news from a social point of view. However, according to Rosling, Rönnlund and Rosling, one need to be alert that many misconceptions can be attributed to human tendency to focus on the negative (2018). Rosling's studies show that individuals express their opinions by systematically referring to false facts, which leads to misconceptions and evokes fear (De Waard, 2018). An objective evaluation thus proves more difficult to pursue in practice, which can be dedicated to the ignorance of many (De Waard, 2018; Rosling et al., 2018). Metaphorically speaking, the heart of fake news is 'adoption', while 'ignorance' flow as blood through the veins and, thus, is keeping fake news alive. An investigative and discerning attitude reduces the blood supply, i.e. a direct observation of the aforementioned situation in the box "prevents us from so naively accepting as valid a 'blurred model' for representing reality" (Schrödinger, 1935, p. 157).

\section{Implications}

The findings of this study have several implications. A theoretical implication is that these findings contribute to the limited body of research on financial fake news (Devos et al., 2002; Kimmel, 2004) as this study reveals that it is a comprehensive concept that contains multiple variants and is diffused for various reasons by different disseminators. Because of these ambiguities it is difficult to define fake news. Another theoretical implication is that the

${ }^{26}$ In the unregulated world of bitcoin and cryptocurrency, fraudsters are deliberately disseminating fake news to affect the price of their own holdings (Mac \& Lytvynenko, 2018). 
findings contribute to the research in the field of management accounting. When including the role of the controller in counteracting fake news, this study reveals that the controller mostly plays an indirect role in counteracting fake news due to the nature of its activities. The practical implication of this study is that it may help society, the governance, policymakers, journalists, managers, controllers and individuals in gaining a better insight into which party, from a current as well as potential perspective, fulfils which role in disseminating and counteracting fake news.

\section{Limitations of data}

This section consists of a number of limitations of the data that were used during this study. These consider the external validity, internal validity, reliability and construct validity.

The external validity is found to be low as the findings cannot be generalised (Leung, 2015). However, the goal of this exploratory study is not to produce generalizable results, instead it aims to gain a fundamental understanding of the phenomenon of fake news with a main focus on the interviewees' perspectives that can be later tested for generalisability (Baarda et al., 2013; Smith, 2017). In addition, a fundamental understanding of the phenomenon is achieved by interpreting the underlying meaning of what is being told by the interviewees ${ }^{27}$. Thereby, the study is focused in one country, which also limits the generalisation. All the same, there are clear indications that the findings are generally applicable to similar countries.

In view of the internal validity, citations of the transcribed interviews are used in the results section. The internal validity is also ensured to some extent by documenting the coding process in the appendix. An unstructured way of interviewing will nonetheless enable the interviewer to unintentionally guide the participant in a certain direction resulting in an increased possibility of collected biased data (Qu \& Dumay, 2001). The following measures are therefore taken to avoid bias: 1) The questions were asked in a neutral way, 2) if desired, the transcripts of the interviews were sent to the interviewees by e-mail, so they can verify the accuracy of it and thereby avoid biased considerations and conclusions, and, to conclude 3) the data were transcribed as soon as possible after the interview (Lillis, 2006; Saunders et al., 2011).

For qualitative research, in general, it is challenging to achieve reliable results. As mentioned by Leung (2015), "the essence of reliability for qualitative research lies with consistency" (p. 326). Hence, the reliability of the process and results is enhanced by following the GTM among which doing a constant comparative analysis (Charmaz, 2014; Silverman, 2013). A limitation that specifically applies to the conducted interviews is the translation process of the transcribed interviews from Dutch to English, which can result in errors or misinterpretations. To limit the chance of bias, the transcripts are translated as literally as possible.

To conclude, construct validity is established by following the operational processes of the GTM, a methodology that best fits the research goal and desired outcome of this study ${ }^{28}$. However, the use of sensitizing concepts, the constructivist approach and the phenomenological orientation may increase the subjectivity of the results as the researcher makes selections from the own analytical process, constructs a story and studies the own conscious experience (Charmaz, 2014). In particular, GTM contains an issue of reliability with respect to the coding of the interviews, since the interviewing and coding were performed by

27 In line with the phenomenological orientation as mentioned in Section 2.2.

${ }^{28}$ For the explanation of the best fit, see Section 2.1 and Section 2.2. 
same person (Smith, 2017). This matter of fact creates potential for researcher bias as the inductive conclusions are derived from a superficial analysis of gathered data (Gasson, 2004). However, research in the field of psychology reveals that all human reasoning can be seen as equilibrium of deductive and inductive reasoning (Simon, 1957). Thereby, the interpretations are validated through constantly comparing one piece of data to another. This way, the researcher has endeavoured to be as objective as possible (Charmaz, 2014; Corbin \& Straus, 2008).

\section{Recommendations}

In this paragraph, recommendations for future research will be given in the first sub paragraph, after which recommendations for practice will be given in the second sub paragraph.

\section{Recommendations for future research}

Since this is an exploratory study, it can serve as a basis for future studies. This study suggests, thus, several opportunities for future research.

As financial fake news is a considerably unexplored phenomenon, especially in the field of business research, it might be interesting to conduct a more in-depth explorative research on one level of analysis instead of four, for instance by doing a single or multiple case study approach on the aforementioned SpaceX project in Section 5.2.

Moreover, future qualitative studies can build further on the proposed conceptual model and examine the connections that have been made. It could for instance be interesting to study the role of the controller in counteracting financial fake news in a quantitative way by establishing whether there is a connection between the absence of fake news and the built-in controls to prevent fake news. Thereafter, it can be investigated whether there are implications for internal as well as external auditors in performing an audit on these controls. Besides that, as mentioned in Section 5.2, the results may indicate an underestimation the impact and presence of fake news. Therefore, it would be useful to investigate the impact of fake news on the reputation of the firm through conducting an experimental study.

In view of this study's results, it could be interesting to further investigate the underlying reasons for the conflicting answers found in this study. The results show that the interviewees are not unanimous about the possibility to prevent fake news. Further investigation into such aspects is therefore advisable, for instance by observing group discussions.

Finally, the aforementioned limitations can also guide future research. As this study focuses on the Netherlands, it will benefit the generalisability of the findings to conduct the same type of study in other countries and compare the findings. Moreover, for a higher validity of the findings, survey studies can be conducted among controllers from large firms. Based on the results from this study, focused survey questions can be formulated.

It is, however, in the interest of future studies to formulate a clear definition about fake news generally and financial fake news more specifically, so that there is clarity about what is covered by it. Another suggestion is therefore to conduct a more in-depth research into the readers' perceptions of fake news.

\section{Recommendations for practice}

Based on the main findings and the final conclusion, a number of practical recommendations will be provided. These recommendations will concern various ways in which the countering 
of fake news can be improved. Each bullet points below represent a subject of recommendation that will be explained in the subsequent paragraphs:

- Continuous evaluation and fundamental principles;

- Fake news scenarios;

- Proactive control and mitigation of non-rational thinking;

- Scepticism and alertness.

As mentioned in the Introduction Section of this report, the phenomenon of fake news is of all times. Still, the phenomenon evolves as society is always in motion. That being the case, it is recommended to the parties involved to evaluate its impact on an ongoing basis. An important aspect to consider are the circumstances under which individuals authenticate news, but also the underlying motives they have for considering it as true news. Moreover, when determining the approach to counteract fake news, a proper weighing up of priorities should be achieved. It is therefore advisable to take into account that countermeasures must not be taken at the expense of other fundamental principles, such as freedom of expression. A new Minister or Propaganda (e.g. the aforementioned Goebbels in Section 1.2) whose acts are in conflict with Dutch democratic values is after all undesirable.

At the time of writing, policymakers are working on the issue of counteracting fake news (NU.nl, 2018). Since the consequences of fake news are unknown, the recommendation to them, but also to firms, is to develop different fake news scenarios, among which a worst-case scenario. The scenarios can be divided into gradations, forms, source, and type of fake news and so on. Based on those scenarios, the potential danger of fake news can be determined.

The results show, however, that the interviewees share the opinion that their firm's current control framework and firm policies procedures are sufficient capable to control risks arising from fake news. Nonetheless, as stated in the Introduction Section, it should be taken into account that the scenarios developed by the firm can become reality. Then, it could be questioned whether the current controls can still sufficiently mitigate the consequences. It is therefore recommended to test the current controls against those scenarios.

The controller can support in gaining awareness and control of fake news that can lead to more clarity of its most significant, financial, consequences on the firm. This level of control can only be reached by first comprehending the fundamentals of fake news itself, which in turn can be characterised as a multidimensional problem. Increasing the focus on fake news can ultimately lead to the development of analytical techniques which enable to forecast, measure and express its significant consequences on the firm, initiating a shift from reactive to proactive control within the controlling function.

Given that rational and ethical considerations play an important role in both the pursuit of transparency and the exercise of the controlling function, it is also advisable that the controller ensures that he is not guided by his own prejudices about the news. Assembling a varied team with different personalities from diverse professional backgrounds can mitigate non-rational thinking and thus more optimally manage the risks related to fake news.

To conclude, regulation is only possible to a certain extent. An initial step of the dissemination is already conducted when it is determined whether a news item is fake or not. Consequently, from the recipients' perspective, more attention needs to be paid to the individuals' ability to recognise fake news as they can be taught how to be more sceptical about the validity of news items. It can be compared to the kind of scepticism that controllers must pursue in the 
professional execution of their profession. An example of this scepticism is the comparison of information published by opposing left wing and right wing sources, as mentioned in the literature section of this report. From the disseminators' perspective, an element of specific importance is whether employees are aware of what information they divulge about the firm and in what way they formulate that information. After all, news can have value for its readers, even when in its core it can be considered to be fake.

\section{Concluding words}

This fundamental study at the frontiers of knowledge contributes in a substantial manner to science by offering perspectives to new scientific endeavours. It also highlights the existing ambiguity about the essence of the phenomenon of fake news in both science and practice. As a result, fake news is given free rein to manifest on all levels explored in this study. This socially relevant phenomenon should therefore receive more attention, both in science and in practice. In concrete terms, this means improvements of the general understanding about the phenomenon of fake news, including improvements in counteractive actions based thereon or resulting therefrom, should be pursued.

Groningen, September 2018

\section{References}

AFM. (n.d.). About AFM. Retrieved May 25, 2018, from https://www.afm.nl/en/over-afm.

Allcott, H., \& Gentzkow, M. (2017). Social media and fake news in the 2016 election. Journal of Economic Perspectives, 31(2), 211-237.

Baarda, D. B., De Goede, M. P. M., \& Teunissen, J. (2013). Basisboek kwalitatief onderzoek : handleiding voor het opzetten en uitvoeren van kwalitatief onderzoek. Groningen: Noordhoff.

Blackstone, A. (2012). Principles of Sociological Inquiry Qualitative and Quantitative Methods. The Saylor Foundation.

Blanshard, B. (n.d.). Rationalism. Encyclopædia Britannica Online. Encyclopædia Britannica Inc. Retrieved February 19, 2018, from https://www.britannica.com/topic/rationalism.

Bloor, D. (1981). The strengths of the strong programme. Philosophy of the Social Sciences, 11(2), 199-21.

Bluhm, D. J., Harman, W., Lee, T. W. \& Mitchell, T.R. (2011). Qualitative Research in Management: A Decade of Progress. Journal of Management Studies, 48(8), 1866-1891.

Boardman, J., \& Sauser, B. (2013). Systemic thinking: Building maps of worlds of systems. Hoboken, New Jersey: John Wiley \& Sons.

Bowen, G. A. (2006). Grounded theory and sensitizing concepts. International journal of qualitative methods, 5(3), $12-23$.

Bryant, A. (2017). Grounded theory and grounded theorizing : Pragmatism in research practice. New York, NY: Oxford University Press.

Charmaz, K. (1995). Grounded theory. In J. Smith, R. Harré, \& L. Langenhove (Eds.), Rethinking methods in psychology (pp. 27-65). London: Sage Publications.

Charmaz, K. (2014). Constructing grounded theory. London: Sage Publications.

Charmaz, K., \& McMullen, L. M. (2011). Five ways of doing qualitative analysis: Phenomenological psychology, grounded theory, discourse analysis, narrative research, and intuitive inquiry. Guilford Press.

Cho, J. Y., \& Lee, E. H. (2014). Reducing confusion about grounded theory and qualitative content analysis: Similarities and differences. The qualitative report, 19(32), 1-20.

Clarke, A.E. (2005). Situational analysis. Grounded theory after the postmodern turn. Thousand Oaks: Sage Publications .

Clarke, A. E., Friese, C., \& Washburn, R. (2016). Situational analysis in practice: Mapping research with grounded theory. Routledge. 
Corbin, J. \& Strauss, A. (2008). Basics of Qualitative Research: Techniques and procedures for developing grounded theory ( $3^{\text {rd }}$ edition). Los Angeles: Sage Publications.

Creswell, J.W. (2009). Research Design: Qualitative, Quantitative, and Mixed Approaches. Thousand Oaks: Sage Publications.

Loo, I. de. B. Verstegen, \& D. Swagerman (2011), 'Understanding the roles of management accountants', European Business Review, vol. 23, no. 3, 287-313.

De Vrieze, J. (2018, January 11). Bruno Latour over feiten, fouten, kritiek en wetenschap: De waarheid vereist hard werken. De Groene Amsterdammer, 142(1-2), 85-87.

De Waard, M. (2018, June 15). Feiten als therapie in tijden van 'fake news'. Het Financieele Dagblad. Retrieved from https://fd.nl/weekend/1257758/feiten-als-therapie-in-tijden-van-fake-news.

Devos, T., Spini, D., \& Schwartz, S. H. (2002). Conflicts among human values and trust in institutions. British Journal of Social Psychology, 41(4), 481-494.

Digital Shadows. (2017). The Business of Disinformation: A Taxonomy. Retrieved from https://resources.digitalshadows.com/whitepapers-and-reports/the-business-of-disinformation-fake-news.

Encyclo. (n.d.). Ontology. Retrieved February 18, 2018, from http://www.encyclo.nl/begrip/ontologie.

Ernst \& Young LLP. (2011). The changing role of the financial controller. Retrieved from http://www.ey.com/Publication/vwLUAssets/Changing_role_of_the_financial_controller/\$FILE/EY_Financial_con troller_changing_role.pdf

Flood, C. (2017, May 5). Fake news infiltrates financial markets. Financial Times. Retrieved from https://www.ft.com/content/a37e4874-2c2a-11e7-bc4b-5528796fe35c.

Fm.nl. (2017, March 15). Fake news is helaas big business. Retrieved from https://financieelmanagement.nl/artikel/fake-news-is-helaas-big-business.

Franzén, T. (2005). Gödel's theorem: an incomplete guide to its use and abuse. Natick, MA: AK Peters.

Freud, S. (1933). Neue Folge der Vorlesungen zur Einfuhrung in die Psychoanalyse. Gesammelte Werke, 5-208.

Gall, M. D., Borg, W. R., \& Gall, J. P. (1996). Educational research: An introduction (6 ${ }^{\text {th }}$ ed.). White Plains, NY: Logman Publishers.

Gasson, S. (2004). Rigor in grounded theory research: An interpretive perspective on generating theory from qualitative field studies. The handbook of information systems research, 4, 79-102.

Glaeser, E. L., \& Ujhelyi, G. (2010). Regulating misinformation. Journal of Public Economics, 94(3), 247-257.

Glaser, B. (1978). Theoretical sensitivity : Advances in the methodology of grounded theory. Mill Valley, Calif.: Sociology Press.

Glaser, B., \& Strauss, A. (1967). The discovery of grounded theory: Strategies for qualitative research (Observations). Chicago: Aldine Pub.

Granlund, M., \& Lukka, K. (1998). Towards increasing business orientation: Finnish management accountants in a changing cultural context. Management Accounting Research, 9, 185-211.

Gray, E. R., \& Balmer, J. M. (1998). Managing corporate image and corporate reputation. Long range planning, 31(5), 695-702.

Historiek. (2015, December 10). Joseph Goebbels - Minister van propaganda onder Adolf Hitler. Retrieved on 28 April 2018, from https://historiek.net/joseph-goebbels-minister-propaganda/3057/.

Homburg, C., Klarmann, M., \& Schmitt, J. (2010). Brand awareness in business markets: When is it related to firm performance? International Journal of Research in Marketing, 27(3), 201-212.

Horlings, A. (2018, April 15). Nepnieuws is van alle tijden: Misleiding basis voor heksenwaan, jodenvervolging en Deutsches Reich. Retrieved April 18, 2018, from https://historiek.net/nepnieuws-is-van-alle-tijden/78499/.

Hosenball, M., \& Menn, J. (2017, April 21). Experts say automated accounts sharing fake news ahead of French election. Retrieved February 14, 2018, from https://www.reuters.com/article/us-france-electionsocialmedia/experts-say-automated-accounts-sharing-fake-news-ahead-of-french-election-idUSKBN17M31G. 
IAASB. (2016). Handbook of International Quality Control, Auditing, Review, Other Assurance, and Related Services Pronouncements (2016-2017 Edition). Retrieved from https://www.ifac.org/publications-resources/2016-2017handbook-international-quality-control-auditing-review-other.

I\&O Research. (2017). Desinformatie leidt tot verwarring bij nieuwsconsument: Onderzoek voor de Volkskrant. Retrieved from

https://ioresearch.nl/Portals/0/Rapport\%20Nepnieuws\%20Volkskrant\%20Versie\%2019122017.pdf.

Investopedia. (n.d.). Dotcom Bubble. Retrieved May 24, 2018, from

https://www.investopedia.com/terms/d/dotcom-bubble.asp.

Jablonsky, S., \& Barsky, N. (2000). The digital workplace: how is it changing the role of financial management? The Journal of Corporate Accounting and Finance, 11(5), 3-10.

James, W. (1907). Pragmatism's Conception of Truth. The Journal of Philosophy, Psychology and Scientific Methods, 4(6), 141-155.

Jia, M., Ruan, H., \& Zhang, Z. (2017). How rumours fly. Journal of Business Research, 72, 33-45.

Katsirikou, A., \& Lin, C. S. (2017). Revealing the "Essence” of Things: Using Phenomenology in LIS Research. Qualitative and Quantitative Methods in Libraries, 2(4), 469-478.

Keersmaecker de, J., \& Roets, A. (2017). 'Fake news': Incorrect, but hard to correct. The role of cognitive ability on the impact of false information on social impressions. Intelligence, 65, 107-110.

Kim, D. H. (1999). Introduction to systems thinking (Vol. 16). Waltham, MA: Pegasus Communications.

Kimmel, A. J. (2004). Rumours and the financial marketplace. The Journal of Behavioral Finance, 5(3), $134-141$.

Klok, P. (2017, November 15). Kijk niet naar mensen die nepnieuws verspreiden, maar naar hen die het geloven. De Volkskrant. Retrieved from https://www.volkskrant.nl/opinie/kijk-niet-naar-mensen-die-nepnieuwsverspreiden-maar-naar-hen-die-het-geloven a4539038/.

Kohn, L., \& Christiaens, W. (2012). KCE Process Book. Retrieved from http://processbook.kcefgov.be/book/export/html/346.

Koops, E. (2017, March 10). Otto von Bismarck (1815-1898) - “IJzeren Kanselier” van Duitsland. Retrieved on 28 April 28, from https://historiek.net/otto-von-bismarck-kanselier-duitsland/67682/.

Kreijveld, M. (2018a). De strijd tegen nepnieuws (2): Wie checkt de factcheckers? Retrieved from https://marketingfacts.nl/berichten/strijd-tegen-nepnieuws-2-wie-checkt-de-factcheckers.

Kreijveld, M. (2018b). De strijd tegen nepnieuws (1): Hoe pak je fake-news aan als niemand weet wat het precies is? Retrieved from https://www.marketingfacts.nl/berichten/strijd-tegen-nepnieuws-1-definitie-en-hoebestrijden.

Kuchler, H. (2017, August 22). Companies scramble to combat 'fake news': From Starbucks to Costco, brands have come under attack from hoaxers. Retrieved from https://www.ft.com/content/afe1f902-82b6-11e7-94e2c5b903247afd.

Latour, B., \& Woolgar, S. (1986). Laboratory life: The construction of scientific facts. Princeton, N.J.: Princeton University Press.

Leung, L. (2015). Validity, reliability, and generalizability in qualitative research. Journal of family medicine and primary care, $4(3), 324$.

Levy, R. (2014). Soothing politics. Journal of Public Economics, 120, 126-133.

Lillis, A. M. (2006). Reliability and validity in field study research, in Z. Hoque (ed.), Methodological issues in accounting research: Theories and methods. Spiramus Press, London: 461-475.

Lillis, A. M., \& Mundy, J. (2005). Cross-sectional field studies in management accounting research-closing the gaps between surveys and case studies. Journal of management accounting research, 17(1), 119-141.

Lloyd, J. (2017, May 25). The truth about the post-truth age. Financial Times. Retrieved from https://www.ft.com/content/53b00158-409c-11e7-82b6-896b95f30f58.

Maas, V. (2005). De rol van de controller in Nederland. Maandblad voor Accountancy en Bedrijfseconomie, 5, $16-20$.

Mac, R., \& Lytvynenko, J. (2018, January 18). Here’s How Scammers Are Using Fake News To Screw With Bitcoin Investors. Retrieved June 19, 2018, from https://www.buzzfeed.com/ryanmac/heres-how-scammers-are-usingfake-news-to-screw-with-bitcoin?utm_term=.lvPKbj041\#.qiYg4AKMP. 
Moustakas, C. (1994). Phenomenological research methods. Thousand Oaks: Sage.

NU.nl. (2018, January 16). 'Europees keurmerk voor echt nieuws en nepnieuws mogelijk'. Retrieved February 16 , 2018, from https://www.nu.nl/media/5089721/europees-keurmerk-echt-nieuws-en-nepnieuws-mogelijk.html.

Oostdijk, J., Zwiep, R. (2014). De controller van Nu \& Straks. Tijdschrift Controlling, 29, 14-17.

Orwell, G. (1946). Politics and the English Language. Horizon, 13(76), 252-265.

Pasztor, A. (2018, May 10). Elon Musk Predicts Rocket Launches Will Be as Routine as Airline Flights. Retrieved May 24, 2018, from https://www.wsj.com/articles/elon-musk-predicts-rocket-launches-will-be-as-routine-asairline-flights-1525988078.

Patton, M. (2002). Qualitative research and evaluation methods (3 ed.). Thousand Oaks : Sage Publications.

Peirce, C. S. (1877). The fixation of belief. Retrieved from:

http://www.commens.org/bibliography/journal_article/peirce-charles-s-1877-fixation-belief, 14.09.20181877.

Peress, J. (2014). The media and the diffusion of information in financial markets: Evidence from newspaper strikes. Journal of Finance, 69(5), 2007-2043.

Radcliffe, V. S. (2010). Discussion of “The world has changed - have analytical procedure practices?" Contemporary Accounting Research, 27(2), 701-709.

Ritchie, J., \& Lewis, J. (2013). Qualitative research practice: A guide for social science students and researchers. London: Sage Publications.

Riedijk, F., Tillema, S., \& Moen, E. (2002). De ontwikkeling van de controller in Nederland. Een verkenning van de praktijk. Maandblad voor Accountancy en Bedrijfseconomie, 76(7/8), 337-347.

Rosling, H., Rönnlund, A. R., \& Rosling, O. (2018). Factfulness: Ten Reasons We're Wrong About the World - and Why Things Are Better Than You Think. Flatiron Books.

Rubin, V. L., Chen, Y., \& Conroy, N. J. (2015). Deception detection for news: three types of fakes. Proceedings of the Association for Information Science and Technology, 52(1), 1-4.

Salinas, F. J. (2016). Bruno Latour's pragmatic realism: an ontological inquiry. Global Discourse, 6(1-2), 8-21.

Sanders, P. (1982). Phenomenology: A New Way of Viewing Organizational Research. The Academy of Management Review, 7(3), 353-360.

Sathe, V. (1982). Controller Involvement in Management, Prentice-Hall.

Saunders, M., Lewis, P., Thornhill, A., Booij, M., \& Verckens, J. P. (2011). Methoden en technieken van onderzoek. Pearson Education.

Schrödinger, E., (1935). The present situation in quantum mechanics. Quantum Theory and Measurement (Princeton University Press; Princeton, NJ), 152-167.

Silverman, D. (2013). Doing qualitative research: A practical handbook. Sage Publications.

Simon, H. (1957). Models of Man: Social and Rational. New York: John Wiley.

Simon, H.A., Guetskow, H., \& Kozmetsky, G. (1954). Centralization versus decentralization in organizing the controller's department, The Controllership Foundation.

Smith, A. (1776). The wealth of nations. London, Methuen \& Co.

Smith, M. (2017). Research methods in accounting. London: Sage Publications.

Stiglitz, J. E. (2018, June 19). The Ethical Economist. Retrieved June 19, 2018, from https://www.foreignaffairs.com/reviews/review-essay/2005-11-01/ethical-economist

Stroll, A., \& Martinich, A. P. (n.d.). Epistemology. Retrieved February 19, 2018, from https://www.britannica.com/topic/epistemology.

Ten Rouwelaar, J. A. (2006). Balancing the roles of business unit controllers: An empirical investigation in The Netherlands. EAA congress 2006, Dublin, Ireland

Weinberg, G. M. (1975). An introduction to general systems thinking. Dorset House Publishing Co Inc.,U.S.

Woodcock, G. (n.d.). George Orwell. Retrieved on 26 April 2018, from

https://www.britannica.com/biography/George-Orwell. 
Van der Horst, H. (2018). Nepnieuws - De wereld van desinformatie. Schiedam, The Netherlands: Scriptum.

Verhagen, L. (2017, November 21). Nepnieuws produceren en verspreiden is makkelijker dan ooit: hulpmiddelen liggen voor het oprapen. De Volkskrant. Retrieved from https://www.volkskrant.nl/media/nepnieuws-

produceren-en-verspreiden-is-makkelijker-dan-ooit-hulpmiddelen-liggen-voor-het-oprapen a4540410/.

Zimmerman, J.L. (2005). Accounting for Decision making and Control, fifth edition, McGraw-Hill Higher Education. 


\section{APPENDIX: CODING SCHEMES}

This appendix applies to the coding schemes that were used to construct concepts around which the findings of this study are formulated. Tables 3 to 7 will cover the development of the initial codes concerning the five sub-questions, where after the initial codes will be merged into focused codes and a theoretical code in Table 8.

\begin{tabular}{|c|c|c|}
\hline Initial codes & Properties & Examples of interviewees' words \\
\hline Various forms of fake news & $\begin{array}{ll}\text { - } & \text { Outside versus } \\
\text { inside distribution } \\
\text { Distribution by the } \\
\text { established } \\
\text { journalistic order, } \\
\text { by random people } \\
\text { or by competitors } \\
\text { It appears in } \\
\text { different } \\
\text { gradations }\end{array}$ & $\begin{array}{l}\text { - In this case, fake news is that } \\
\text { another company, a competitor, } \\
\text { might give false signals. } \\
\text { - A journalist is always looking for } \\
\text { sensation. } \\
\text { - } \quad \text { I think a lot is being } \\
\text { manipulated, lobbied and done. } \\
\text { - } \quad \begin{array}{l}\text { Different gradations in fake } \\
\text { news }\end{array} \\
\text { - Incorrect information } \\
\text { memorandum or incorrect } \\
\text { newsletters }\end{array}$ \\
\hline No clear definition & $\begin{array}{ll}\text { - } & \text { From a legal and } \\
\text { societal } \\
\text { perspective there } \\
\text { is no clear } \\
\text { definition } \\
\text { Various definitions } \\
\text { exist }\end{array}$ & $\begin{array}{ll}\text { - } & \text { Demagoguery } \\
\text { - } & \text { Falsehoods } \\
\text { - } & \text { Disinformation } \\
\text { - } & \text { Untruths } \\
\text { - } & \text { Alternative facts } \\
\text { - } & \text { False, incorrect or misleading } \\
& \text { information } \\
\text { - } & \text { Bad informed media } \\
\text { - } & \text { Grey area } \\
\end{array}$ \\
\hline $\begin{array}{l}\text { Prevailing uncertainty } \\
\text { among the interviewees } \\
\text { about the meaning of fake } \\
\text { news }\end{array}$ & $\begin{array}{ll} & \text { Different } \\
\text { perceptions of the } \\
\text { meaning of fake } \\
\text { news } \\
\text { - } & \text { Uncertainty } \\
\text { - } & \text { Various definitions }\end{array}$ & $\begin{array}{l}\text { - What is fake news? } \\
\text { - What is the definition of fake } \\
\text { news? } \\
\text { - When is something fake news } \\
\text { and when it is not? I do not } \\
\text { know } \\
\text { It is a very broad concept I think, } \\
\text { it depends on what definition } \\
\text { you use }\end{array}$ \\
\hline $\begin{array}{l}\text { Ignorance about certain } \\
\text { features of the phenomenon }\end{array}$ & $\begin{array}{l}\text { Both intangible } \\
\text { and omnipresent } \\
\text { at the same time } \\
\text { - Unfamiliarity }\end{array}$ & $\begin{array}{ll}- & \text { Unknown impact } \\
\text { - } & \text { Unknown size } \\
\text { - } & \text { Unknown degree of } \\
\text { dissemination } \\
\text { - } & \text { Unknown motives } \\
\text { - } & \begin{array}{l}\text { Unknown which information is } \\
\text { of significance }\end{array} \\
\end{array}$ \\
\hline
\end{tabular}


Table 4 : Initial codes for the second sub-question

\begin{tabular}{|c|c|c|}
\hline Initial codes & Properties & Examples of interviewees' words \\
\hline $\begin{array}{l}\text { The AFM and the Dutch } \\
\text { Press Council apply } \\
\text { corrective } \\
\text { countermeasures to cover } \\
\text { the Dutch citizens against } \\
\text { fake news. }\end{array}$ & $\begin{array}{l}\text { Reactive } \\
\text { measures } \\
\text { The AFM aims to } \\
\text { correct fake news } \\
\text { by warning about } \\
\text { the consequences. } \\
\text { Fake news } \\
\text { receives less } \\
\text { attention by the } \\
\text { Dutch Press } \\
\text { Council. }\end{array}$ & $\begin{array}{l}\text { The role of the AFM can be to } \\
\text { communicate the essential } \\
\text { information to individuals. } \\
\text { The role of the AFM can be to } \\
\text { oblige a disseminator of fake news } \\
\text { to correct it. } \\
\text { So that the AFM can only intervene } \\
\text { after the damage has already been } \\
\text { caused. } \\
\text { We mainly consider whether } \\
\text { journalists comply with certain } \\
\text { codes of conduct at certain codes. } \\
\text { Whether a message is true or less } \\
\text { true receives less attention by us. }\end{array}$ \\
\hline $\begin{array}{l}\text { Increasing awareness for } \\
\text { the phenomenon }\end{array}$ & $\begin{array}{l}\text { - } \\
\text { information for reliable } \\
\text { People become } \\
\text { more aware of } \\
\text { what good } \\
\text { information is } \\
\text { Verifiability of } \\
\text { information }\end{array}$ & $\begin{array}{ll}\text { - } & \text { Increased appreciation for reliable } \\
\text { information } \\
\text { - } \quad \text { Fear of undermining democracy } \\
\text { - } \\
\text { Increased concerns about the } \\
\text { - } \quad \text { Sonsequences of fake news } \\
\text { - } \quad \text { Critical readers must be able to } \\
\text { verify news themselves } \\
\text { - Big dilemma }\end{array}$ \\
\hline $\begin{array}{l}\text { Different perspectives } \\
\text { about who is responsible } \\
\text { for counteracting fake } \\
\text { news }\end{array}$ & $\begin{array}{ll}\text { - } & \text { Task of the media } \\
\text { - } & \text { Task of social } \\
\text { - } & \text { Taskia platforms } \\
\text { - } & \text { legislator } \\
\text { - } & \text { Task of the } \\
\text { - } & \text { Tavernments } \\
\text { - } & \text { Task of everyone }\end{array}$ & $\begin{array}{ll}\text { - } & \text { Specific law about fake news } \\
\text { - } & \text { Self-regulation } \\
\text { - } & \text { Regulation } \\
\text { - } & \text { Transparency in the journalistic } \\
\text { - } & \text { As a companing } \\
\text { correcting the wrong news } \\
\text { - } \quad \text { We are all responsible } \\
\text { - } \quad \text { Th is a social problem. } \\
\quad \text { The responsibility lies also with } \\
\quad \text { the government and with society. }\end{array}$ \\
\hline
\end{tabular}




\begin{tabular}{|c|c|c|}
\hline Initial codes & Properties & Examples of interviewees' words \\
\hline Brand awareness & $\begin{array}{l}\text { - Prominent role in } \\
\text { the market } \\
\text { Possible higher } \\
\text { impact on the } \\
\text { reputation }\end{array}$ & $\begin{array}{ll}\text { - } & \text { Market player } \\
\text { - } & \text { You have to take into account } \\
\text { what is happening in the market } \\
\text { - }\end{array}$ \\
\hline $\begin{array}{l}\text { Many options and capital } \\
\text { available to analyse and } \\
\text { counteract fake news }\end{array}$ & $\begin{array}{l}\text { More capacities to } \\
\text { monitor } \\
\text { developments in } \\
\text { the market than } \\
\text { the smaller firms } \\
\text { - Presence of a } \\
\text { Communication } \\
\text { Department }\end{array}$ & $\begin{array}{l}\text { You can temporarily deploy some } \\
\text { employees who perform these } \\
\text { data analyses. } \\
\text { You are able to discover } \\
\text { consistencies faster due to having } \\
\text { more computing capacity } \\
\text { available. } \\
\text { We have a Communication } \\
\text { Department. }\end{array}$ \\
\hline $\begin{array}{l}\text { Communication } \\
\text { Department plays an } \\
\text { prominent role in } \\
\text { counteracting fake news }\end{array}$ & $\begin{array}{ll} & \text { Presence of a } \\
\text { Communication } \\
\text { Department }\end{array}$ & $\begin{array}{l}\text { - } \quad \begin{array}{l}\text { Plays an pivotal role in } \\
\text { counteracting fake news } \\
\text { - }\end{array} \text { Plays an important role in } \\
\text { counteracting fake news } \\
\text { - } \quad \begin{array}{l}\text { Keeps an eye on discussions and } \\
\text { argumentations on the Internet }\end{array} \\
\text { - } \quad \text { Makes assessment of how to react } \\
\text { - Signals inaccuracies about the firm } \\
\text { from their position }\end{array}$ \\
\hline $\begin{array}{l}\text { Discrepancy between } \\
\text { types of firms in } \\
\text { approaching fake news }\end{array}$ & $\begin{array}{l}\text { Some firms attach more } \\
\text { importance to } \\
\text { counteracting fake news } \\
\text { than others }\end{array}$ & $\begin{array}{l}\text { - } \quad \begin{array}{l}\text { Fake news is more short term } \\
\text { orientated }\end{array} \\
\text { - } \quad \text { We value in the long term } \\
\text { - } \quad \text { Short and long-term issues do } \\
\text { balance out }\end{array}$ \\
\hline
\end{tabular}




\section{Table 6 : Initial codes for the fourth sub-question}

\begin{tabular}{|c|c|c|}
\hline Initial codes & Properties & Examples of interviewees' words \\
\hline $\begin{array}{l}\text { Uncertainty about the } \\
\text { impact and frequency of } \\
\text { fake news }\end{array}$ & $\begin{array}{l}\text { Fake news is not considered } \\
\text { as a threat to the firm's } \\
\text { reputation by everyone. }\end{array}$ & $\begin{array}{ll}\text { - } & \text { I do not think that we are } \\
\text { affected that much by fake news. } \\
\text { - } \quad \text { I think } \\
\text { - } \quad \text { I cannot prove that } \\
\text { - } \quad \text { Presumably } \\
\text { - } \quad \text { There may be some fake news } \\
\quad \text { here and there. }\end{array}$ \\
\hline $\begin{array}{l}\text { Uncertainty about the } \\
\text { deliberate damage motive } \\
\text { of fake news }\end{array}$ & 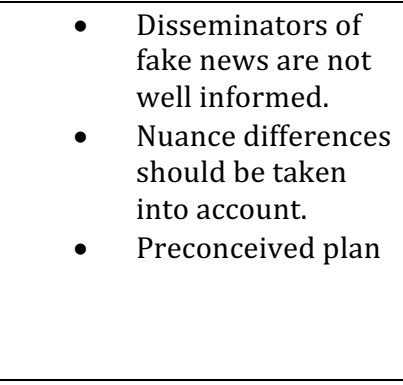 & $\begin{array}{ll}\text { - } & \text { Not well informed about facts. } \\
\text { - } & \text { This is a nuance difference. } \\
\text { Not come across fake news that } \\
\text { is knowingly and intentionally } \\
\text { disseminated about our firm. } \\
\text { - } \quad \text { Completely lacks context or } \\
\text { nuance. } \\
\text { - We see in many cases that this } \\
\text { was a preconceived plan. } \\
\text { - No error or mistake or mistake. }\end{array}$ \\
\hline Context specific & $\begin{array}{l}\text { Best way to } \\
\text { counteract fake } \\
\text { news is dependent } \\
\text { of the specific } \\
\text { situation } \\
\text { Differences in } \\
\text { firm's approaches } \\
\text { of countering fake } \\
\text { news } \\
\end{array}$ & $\begin{array}{l}\text { - } \text { A firm has certain stakeholders } \\
\text { with which the relationship } \\
\text { must remain good. } \\
\text { - } \quad \text { Wrong image of the firm } \\
\text { - } \quad \text { Pistinction between sectors } \\
\text { - } \quad \text { It are more reactive actions }\end{array}$ \\
\hline Transparent and accessible & $\begin{array}{l}\text { - } \\
\text { Transparency } \\
\text { The reaction of the } \\
\text { firm should be in } \\
\text { line with the } \\
\text { language that } \\
\text { readers } \\
\text { understand. } \\
\text { Availability of } \\
\text { information }\end{array}$ & $\begin{array}{l}\text { Important to be transparent. } \\
\text { - } \quad \text { In line with the language that } \\
\text { readers understand. } \\
\text { Creating as much openness and } \\
\text { transparency as possible, while } \\
\text { ensuring that the information is } \\
\text { available to various sources. } \\
\text { Proactively communicating } \\
\text { about very sensitive topics }\end{array}$ \\
\hline $\begin{array}{l}\text { Different circumstances } \\
\text { under which fake news can } \\
\text { occur }\end{array}$ & $\begin{array}{ll}\text { - } & \text { Not qualifying } \\
\text { news equally } \\
\text { - } & \text { Being uncritical } \\
\text { - } & \text { Not recognising } \\
\text { that there are good } \\
\text { and less good } \\
\text { sources } \\
\text { - } \text { Inaccurate } \\
\text { selection and } \\
\text { assessment of } \\
\text { news reports by } \\
\text { websites } \\
\text { Time pressure and } \\
\text { constant demand } \\
\text { for new reports } \\
\text { amongst news } \\
\text { reporters }\end{array}$ & $\begin{array}{l}\text { - } \quad \begin{array}{l}\text { Disqualification of news that } \\
\text { people do not like }\end{array} \\
\text { - } \quad \text { Have been uncritical for too long } \\
\text { One needs to analyse the news } \\
\text { more } \\
\text { - } \quad \begin{array}{l}\text { One should recognise that there } \\
\text { are good and less good sources }\end{array} \\
\text { - Too little time to check new } \\
\text { reports } \\
\text { - Constant demand for new } \\
\text { reports } \\
\text { Press to attract as many visitors } \\
\text { as possible } \\
\text { A journalist can convince } \\
\text { readers that he or she has to be } \\
\text { taken more seriously than } \\
\text { others. }\end{array}$ \\
\hline
\end{tabular}


Table 7 : Initial codes for the fifth sub-question

\begin{tabular}{|c|c|c|}
\hline Initial codes & Properties & Examples of interviewees' words \\
\hline $\begin{array}{l}\text { Ensuring reliability, } \\
\text { accuracy, correctness, } \\
\text { completeness and current } \\
\text { affairs for all business } \\
\text { economic issues in the } \\
\text { business information } \\
\text { provision. }\end{array}$ & $\begin{array}{l}\text { Guaranteeing the } \\
\text { reliability of the } \\
\text { information } \\
\text { provision. } \\
\text { Ensuring the } \\
\text { accuracy and } \\
\text { completeness of } \\
\text { the financial } \\
\text { statements. } \\
\text { - } \\
\text { Risk management } \\
\text { Control products } \\
\text { are the entire } \\
\text { integral business } \\
\text { information } \\
\text { provisions. }\end{array}$ & $\begin{array}{l}\text { - As a controller, you are of course } \\
\text { also talking about the reliability } \\
\text { of the firm. } \\
\text { - Ensuring that all the facts are on } \\
\text { the table } \\
\text { - Will not manipulate the market } \\
\text { - Cover the risk of market } \\
\text { manipulation } \\
\text { - Responsible for the control } \\
\text { products, so the entire integral } \\
\text { business information provision } \\
\text { and all its facets. }\end{array}$ \\
\hline $\begin{array}{l}\text { Decision-making and } \\
\text { monitoring role }\end{array}$ & $\begin{array}{l}\text { Actual weighing up } \\
\text { of pros and cons. } \\
\text { Checking for facts } \\
\text { and inaccuracies. }\end{array}$ & $\begin{array}{l}\text { - } \quad \text { You are actually weighing up the } \\
\text { pros and cos of decisions to } \\
\text { make. } \\
\text { - } \quad \text { Drawing up the annual accounts. } \\
\text { - } \quad \text { Reading the annual report. } \\
\text { Always looking at the actual } \\
\text { facts. }\end{array}$ \\
\hline $\begin{array}{l}\text { Broad versus more } \\
\text { narrowly orientated } \\
\text { controllers }\end{array}$ & $\begin{array}{l}\text { Financial orientated } \\
\text { controllers deals } \\
\text { more with financial } \\
\text { issues, while } \\
\text { business orientated } \\
\text { controllers deals } \\
\text { with several } \\
\text { business aspects. }\end{array}$ & $\begin{array}{ll}\text { - } & \text { More involved in financial issues } \\
\text { - } & \text { Deals with all business aspects } \\
& \text { Closely focused on, for instance, } \\
\text { investment proposals }\end{array}$ \\
\hline $\begin{array}{l}\text { No clarity about the role of } \\
\text { the controller in } \\
\text { counteracting fake news. }\end{array}$ & 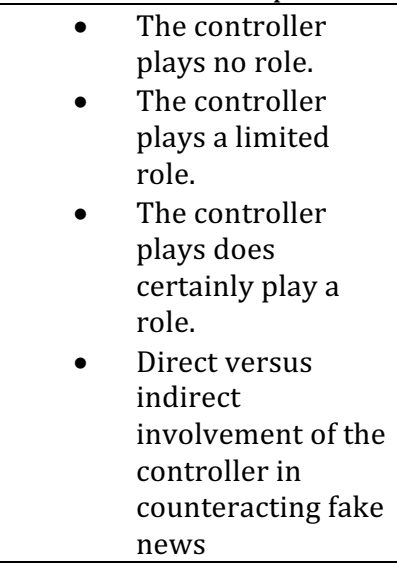 & $\begin{array}{ll}\text { - } & \text { Communication Department } \\
& \text { plays an important pivotal role } \\
\text { - } & \text { Facilitating role } \\
\text { - } & \text { Limited role } \\
\text { - } & \text { Does certainly play an role } \\
\text { - } & \text { Not a core activity } \\
\text { - } & \text { Indirectly part of the tasks of the } \\
& \text { general and legal managers } \\
\text { - } & \text { Not an active part of my role } \\
\text { - } & \text { It is indirectly part of it. }\end{array}$ \\
\hline
\end{tabular}




\section{Table 8 : Focused codes and theoretical codes based on the initial codes}

\begin{tabular}{|c|c|c|}
\hline Initial codes & Focused codes & Theoretical code \\
\hline $\begin{array}{ll}\text { - } & \text { Various forms of fake news } \\
\text { - } & \text { Various motives for spreading } \\
\text { - } & \text { fake news } \\
\text { - } & \text { Prevailing uncertainty among } \\
\text { the interviewees about the } \\
\text { meaning of fake news } \\
\text { - } \quad \begin{array}{l}\text { Ignorance about certain } \\
\text { features of the phenomenon }\end{array}\end{array}$ & $\begin{array}{l}\text { No univocal understanding } \\
\text { of the phenomenon of fake } \\
\text { news }\end{array}$ & \multirow[t]{5}{*}{$\begin{array}{l}\text { Professional scepticism of } \\
\text { the society, large firms } \\
\text { and controllers is } \\
\text { required for being vigilant } \\
\text { in recognising (financial) } \\
\text { fake news risks. }\end{array}$} \\
\hline $\begin{array}{l}\text { The AFM and the Dutch Press } \\
\text { Council apply corrective } \\
\text { countermeasures to cover the } \\
\text { Dutch citizens against fake } \\
\text { news } \\
\text { - Increasing awareness for the } \\
\text { phenomenon } \\
\text { Different perspectives about } \\
\text { who is responsible for } \\
\text { counteracting fake news }\end{array}$ & $\begin{array}{l}\text { The task of counteracting } \\
\text { fake news lies with all } \\
\text { parties involved. }\end{array}$ & \\
\hline $\begin{array}{ll}\text { - } & \text { Brand awareness } \\
\text { - } & \text { More options and capital } \\
\text { available to analyse and } \\
\text { counteract fake news } \\
\text { - } \quad \text { Communication Department } \\
\text { plays an prominent role in } \\
\text { counteracting fake news } \\
\text { Discrepancy between types of } \\
\text { firms in approaching fake news }\end{array}$ & $\begin{array}{l}\text { More specialised approach } \\
\text { in counteracting fake news } \\
\text { compared to smaller firms }\end{array}$ & \\
\hline $\begin{array}{l}\text { - Uncertainty about the impact } \\
\text { - } \quad \text { Und frequency of fake news } \\
\text { deliberate damage motive of } \\
\text { fake news } \\
\text { - } \quad \text { Context specific } \\
\text { - Transparent and accessible } \\
\text { - } \quad \text { Different circumstances under } \\
\text { which fake news can occur }\end{array}$ & $\begin{array}{l}\text { Firm specific approach in } \\
\text { counteracting specific cases } \\
\text { of fake news }\end{array}$ & \\
\hline $\begin{array}{l}\text { Ensuring reliability, accuracy, } \\
\text { correctness, completeness and } \\
\text { current affairs for all business } \\
\text { economic issues in the business } \\
\text { information provision. } \\
\text { Decision-making and } \\
\text { monitoring role } \\
\text { Broad versus more narrowly } \\
\text { orientated controllers } \\
\text { No clarity about the role of the } \\
\text { controller in counteracting fake } \\
\text { news. }\end{array}$ & $\begin{array}{l}\text { The controller as the } \\
\text { (business-economic) } \\
\text { conscience of the firm }\end{array}$ & \\
\hline
\end{tabular}

